\title{
Applying national liability law to transboundary pollution: some lessons from Europe and the United States
}

Citation for published version (APA):

Faure, M. G., \& Betlem, G. (2008). Applying national liability law to transboundary pollution: some lessons from Europe and the United States. In M. Faure, \& Y. Song (Eds.), China and International Environmental Liability. Legal Remedies for Transboundary Pollution (pp. 129-191). Edward Elgar Publishing. New Horizons in Environmental Law http://ssrn.com/abstract=1498468

Document status and date:

Published: 01/01/2008

\section{Document Version:}

Publisher's PDF, also known as Version of record

\section{Document license:}

Taverne

Please check the document version of this publication:

- A submitted manuscript is the version of the article upon submission and before peer-review. There can be important differences between the submitted version and the official published version of record.

People interested in the research are advised to contact the author for the final version of the publication, or visit the DOI to the publisher's website.

- The final author version and the galley proof are versions of the publication after peer review.

- The final published version features the final layout of the paper including the volume, issue and page numbers.

Link to publication

\footnotetext{
General rights rights.

- You may freely distribute the URL identifying the publication in the public portal. please follow below link for the End User Agreement:

www.umlib.nl/taverne-license

Take down policy

If you believe that this document breaches copyright please contact us at:

repository@maastrichtuniversity.nl

providing details and we will investigate your claim.
}

Copyright and moral rights for the publications made accessible in the public portal are retained by the authors and/or other copyright owners and it is a condition of accessing publications that users recognise and abide by the legal requirements associated with these

- Users may download and print one copy of any publication from the public portal for the purpose of private study or research.

- You may not further distribute the material or use it for any profit-making activity or commercial gain

If the publication is distributed under the terms of Article $25 \mathrm{fa}$ of the Dutch Copyright Act, indicated by the "Taverne" license above, 


\section{Maastricht University}

Faculty of Law

\section{Applying national liability law to transboundary pollution: \\ some lessons from Europe and the United States}

Michael Faure \& Gerrit Betlem

All rights reserved. No parts of this paper may be reproduced in any form without the permission of the author(s).

This paper can be downloaded without charge from the Social Science Research Network electronic library. 


\section{Applying national liability law to transboundary pollution: some lessons from Europe and the US}

Michael Faure and Gerrit Betlem

\section{Introduction}

Examples of transboundary pollution cases can unfortunately be found on almost all continents and have probably since industrialization only increased. Moreover, economists would argue that externalization of harm is a natural phenomenon, not only for individuals and enterprises, but also for political entities like States. Indeed, if politicians would be able to make their own voters enjoy the benefits of economic activities while they could succeed in passing on the costs to others, they would in principle not refrain from doing so. Moreover, politicians will generally not be rewarded for fights against transboundary pollution since the foreign citizen who would benefit from such action cannot support them with votes. In other words: the fact that national politicians would support legislation allowing firms to externalize harm to their neighbours should, from this economic perspective, not come as a surprise. To some extent, it is easy to find examples of this externalizing behaviour, for example if one simply looks at the siting of noxious and dangerous facilities: in many countries, dangerous activities like e.g. nuclear power plants will not be located next to the capital of a particular country, but preferably close to the borders where risks are primarily felt by their neighbours.

Just as within the national context externalities are considered a market failure to which the law should react, the same is the case as well for transboundary environmental harm. In the absence of legal rules which force countries to take into account the transboundary pollution they cause, States will have no incentives to do so. The primary goal of international environmental law should therefore, from this simple economic perspective, be no other than the internalization of the transboundary externality caused by pollution.

Of course, some economists may argue that it is not necessary to use legal rules to internalize externalities: Ronald Coase taught that as long as transaction costs are zero, an efficient internalization, also of transboundary externalities, could take place via bargaining between the parties. Some economists have indeed suggested that for example as far as small scale 
pollution is concerned, this type of bargaining may result in an efficient internalization of the harm. ${ }^{1}$ However, experience shows that so far very few transboundary pollution cases have been solved through efficient bargaining. Even in cases where there are only two parties involved (for example an upstream polluting State and a downstream victim State) bargaining which would for example lead to the victim State paying the polluter State to install efficient pollution reduction mechanisms is rare. Even though transaction costs are low, there may be a variety of reasons why efficient bargaining does not take place, one of them being strategic behaviour by the States or political failures as a result of which States would be insufficiently willing to represent the interests of those (small number of) victims actually suffering the harm. Moreover, as soon as the transboundary pollution passes the boundaries of not only one State, but many more States are victimized and complicated causation issues arise, it may be clear that bargaining may not generate efficient results.

Interestingly, economists have always argued that the transboundary character of an externality, like environmental pollution, is one of the primary reasons in favour of shifting powers to a higher level of government. ${ }^{2}$ Hence, it is not difficult to argue from an economic perspective that shifting powers to a higher level of government is an efficient reaction to transboundary pollution. That explains why larger institutional settings like for example the European Union or the Federal State in the US deal more particularly with transboundary pollution problems. Moreover, the central goal of international treaties which form the core of the body of law referred to as international environmental law of course equally aim at this internalization of transboundary environmental externalities. Many contributions to this volume deal indeed with the question how international law, either through State liability or through international conventions can effectively provide this remedy to transboundary pollution. In our paper we will, however, provide a different perspective.

We will examine to what extent national liability rules can be used as an effective remedy to transboundary pollution. Formally, the body of law which we therefore discuss in this paper is not international environmental law (even though we will of course examine to what extent

\footnotetext{
${ }^{1}$ See Cohen, M., “Commentary”, in Eide, E. and Van den Bergh, R.J. (eds.), Law and Economics of the Environment, Oslo, Juridisk Forlag, 1996, 167-171.

${ }^{2}$ See for example Esty, D., “Revitalizing Environmental Federalism”, 95 Michigan Law Review, 1996, 625 and Kimber, C., "A Comparison of Environmental Federalism in the United States and the European Union”, 54 Maryland Law Review, 1995, as well as the classic paper by Oates, W. and Schwab, R., "Economic Competition among Jurisdictions: Efficiency Enhancing or Distortion Inducing?”, 35 Journal of Public Economic, 1988.
} 
international conventions are important in individual liability cases). Instead, we will deal with national tort law and discuss what problems may arise in its application to transboundary pollution cases. By discussing the potential problems, we at the same time also discuss the (potential) solutions.

Indeed, the general argument in our paper is that more particularly for well identified pollution cases, where pollution is kept within reasonable boundaries and polluters can be identified, the application of national tort law to transboundary pollution can to some extent provide an effective remedy. We are in this context of course referring to what can in fact be referred to as an extraterritorial application of national tort law, since the national tort law of (usually) the victim's State will be applied to a pollution which has its origin in the polluter's State.

Even though we will argue that applying national tort law to these transboundary pollution cases has a lot of potential, we equally realize that there are serious limits as well. From the moment that the number of polluters becomes very large or the damage very wide spread, complicated causation issues may arise and the scope for applying national tort law may become more limited. For those cases, the argument in favour of regulation through international conventions becomes stronger. ${ }^{3}$ Nevertheless, one should realize that increasingly authors examine whether also national tort laws can be used to tackle complicated problems where indeed many causation questions arise. In this respect, applying liability law has even been suggested in the literature as a remedy for damage caused by climate change. ${ }^{4}$ Our argument is that given many weaknesses in international treaties in remedying transboundary pollution (more particularly the well-known problems of

\footnotetext{
${ }^{3}$ This complies with the general economic argument made by Steven Shavell that regulation should be used when the deterrent effect of tort rules may be weaker (Shavell, S., "Liability for harm versus regulation of safety”, Journal of Legal Studies, 1984, 357-374 and Shavell, S., "A model of the optimal use of liability and safety regulation”, Rand Journal of Economics, 1984, 271-280).

${ }^{4}$ See for example Faure, M. and Nollkaemper, A., "International liability as an instrument to prevent and compensate for climate change", Stanford Environmental Law Journal (26A)/ Stanford Journal of International Law (43A), Symposium Issue June 2007, 123-179; Gupta, J., Who's afraid of climate change? Inauguration address Free University of Amsterdam, 2005; Grosman, D.A., "Warming up to a not-so radical idea: tort-based climate change litigation", 28 Columbia Journal of Environmental Law, 2003, 1-61; Allen, M., "Liability for climate change. Will it ever be possible to sue anyone for damaging the climate?”, 421 Nature, 2003, 891-892; Verheyen, R., Climate change damage and international law: prevention, duties and State responsibility, Leiden, Nijhoff, 2005 and Spier, J., "Legal aspects of global climate change and sustainable development”, Revista para el Analysis del Derecho, 346, April 2006, available at <http://www.indret.com/pdf/346_\&pdf>.
} 
compliance and enforcement), ${ }^{5}$ there may be ample reasons not to exclude the possibility to apply national tort law to transboundary pollution cases.

The reason we are, moreover, interested in this topic is that there is in many countries in Europe, and more particularly in the Netherlands, considerable experience with the application of national liability law to transboundary pollution cases. Indeed, in the Netherlands both individual victims and non-governmental organizations (NGOs) have successfully filed claims against foreign polluters before Dutch courts. However, we will not merely address Dutch law. Rather, it is intended to provide an agenda indicating the type of problems and questions that may arise if one wishes to use liability law to solve a transboundary environmental pollution problem. By addressing these problems, we will refer to a number of possible solutions, some of them coming from the Netherlands, but also others finding a more general basis in European (environmental) law. By doing so, we hope that also for readers in other continents, it may become clear what type of questions arise in the use of liability law to remedy transboundary pollution problems. In answering these questions, we will be able to rely on some earlier research. ${ }^{6}$ We expand on this earlier work by discussing

\footnotetext{
${ }^{5}$ See with respect to the problems of enforcement and compliance in international law inter alia Jacobsen, H.K. and Brown Weiss, E., "Strenghtening Compliance with International Environmental Accords: Preliminary Observations, from a Collaborative Project”, 1 Global Governance, 1995, 119148; Mitchell, R.B., "Compliance Theory: an Overview”, in Cameron, J., Werksman, J. and Roderick, P. (eds.), Improving Compliance with International Environmental Law, London, Earthscan, 1996, 328 and Faure, M. and Lefevere, J., "Compliance with Global Environmental Policy”, in Axelrod, R.S., Downie, D.L., Vig, N.J. (eds.), The Global Environment. Institutions, Law and Policy, $2^{\text {nd }}$ edition, Washington, CQ Press, 2004, 163-180.

${ }^{6}$ See more particularly Betlem, G., Civil Liability for Transfrontier Pollution. Dutch Environmental Tort Law in International Cases in the Light of Community Law, London, Graham and Trotman, 1993; Betlem, G., "Legal Barriers to Liability for Cross-Border Non-Point Source Pollution”, in Van Dunné, J.M. (ed.), Non-Point Source River Pollution. The Case of the River Meuse. Technical, Legal, Economic and Policy Aspects, London, Kluwer Law International, 1996, 145-158; Betlem, G., "Transnational Litigation against Multinationals before Dutch Courts,” in Kamminga, M. and Zia-Zarifi, S. (eds.), Liability of Multinational Corporations under International Law, The Hague, Kluwer Law International, 2000, 283-305; Betlem, G., "Environmental Liability and the Private Enforcement of Community Law”, in Hartkamp, A. et. al. (eds.), Towards a European Civil Code, Nijmegen, Ars Aequi Libri, 2004, 677-696; Betlem, G. and Bernasconi, C., "European Private International Law, the Environment and Obstacles for Public Authorities,” 122 Law Quarterly Review, 2006, 123-150; Betlem, G., "Transnational Operator Liability”, in Betlem, G. and Brans, E. (eds.), Environmental Liability in the EU. The 2004 Directive compared with US and Member State Law, London, Cameron May, 2006, 149-188; Faure, M., "Juridische Problemen bij de Bestrijding van Grensoverschrijdende Waterverontreiniging” (Case note by Court of Appeal The Hague, 19 November 1992 and President Civil Court of Maastricht, 3 February 1993), Tijdschrift voor Milieurecht, 1993, 157-162 and Betlem, G. and Faure, M., "Environmental Toxic Torts in Europe: Trends in Recovery of Soil Clean-Up Costs and Damages for Personal Injury in the Netherlands, Belgium, England and Germany”, Georgetown International Environmental Law Review, 1998, 855-
} 
the problems that may arise in applying national liability law to transboundary pollution cases at a more abstract level and by using, where useful, the economic analysis of law.

After this introduction (1), the remainder of this contribution will be structured as follows: first, it will generally be analysed to what extent international norms or treaties still play a role in a specific transboundary liability case (2), next the important question will arise before which forum a transboundary liability case can be brought (3) and which law shall be applied (4). Then, the question arises what actors can bring a liability suit and more particularly whether this is restricted to victims suffering actual harm or whether NGO's also have standing (5). Of course, the question needs to be addressed what the applicable liability rules are (6) as well as the applicable remedies, including an examination of ongoing litigation in the US about the use of citizen suits in a transboundary context (7). Also, the question needs to be addressed what the effect may be of following regulations or more particularly standards prescribed in a permit, especially when this permit has been granted by a foreign authority (8). Finally, the question will be addressed how a victim could eventually execute a judgment that he has obtained in the victim State in a polluter State (9) and a few concluding remarks will be formulated (10).

\section{International Law in a Transboundary Liability Case}

\subsection{General: Monism versus Dualism}

Many potential problems of transboundary pollution are now subjected to international regulations in the form of treaties. States are parties to these treaties and the regime of the particular Treaty will determine how the Treaty is enforced and what sanctions may apply in case of non-compliance. As such, it seems as if treaties and the rules contained therein provide a separate world from liability cases. The simple reason seems to be that only States are parties to a Treaty and can therefore on the basis of the classic rule in international law ${ }^{7}$ enjoy benefits or be held liable on the basis of a Treaty. Although this basic Statement is still true today, reality is a bit more complex and balanced. In principle, an individual in either a victim or a polluter State will only be confronted with the contents of a Treaty when this has

890.

${ }^{7}$ See generally Birnie, P.W. and Boyle, A., International Law and the Environment, $2^{\text {nd }}$ ed., Oxford, OUP, 2002, in particular Chapters 3-5. 
been implemented by the national State, in other words if the national State has taken the necessary measures in national law to give effect to the particular Treaty. In that case, as a result of the Treaty, citizens could either enjoy benefits from the Treaty or have obligations imposed upon them as a result of the implementation of the Treaty. An example constitute the conventions on nuclear liability such as the Paris Convention concerning civil liability in the domain of nuclear energy of 29 July 1960 (as many times amended) creates obligations for the licensee of a nuclear power plant in the ratifying States, for example to obtain compulsory insurance coverage up to the amount specified in the convention and grants specific rights to victims to obtain compensation in case of a nuclear accident up to the limits specified in the convention. ${ }^{8}$ After the convention has been implemented in national law, the national legislation of the contracting States imposes these particular obligations or confers particular rights to the citizens within the States. Nevertheless, the question can arise what the situation would be if for example Treaty provisions would not have been adequately implemented in national law or if, more generally, a State would violate obligations (other than those arising from treaties) under international law. The question that interests us here is of course not whether this may give rise to responsibility of the State under international law but whether a particular individual could then call on this violation of international law if he suffers damage as a result of this. A distinction could be made (presenting this in a very simple way) between the situation where it is the victim's own State that has hypothetically failed to implement the Treaty obligation and the situation where this would be another State. Suppose that the victim's State failed to implement the obligations under a Treaty and that the victim claims to suffer damage as a result of that which stands in a causal relationship with the violation of the Treaty obligation. International legal doctrine then holds that one first has to examine whether the particular State of that victim accepts a so-called monistic or a dualistic approach to international legal obligations. In countries where a so-called monistic approach is followed (such as the Netherlands, France and Belgium), international law automatically becomes part of internal law and, provided that the obligations imposed upon the State in the Treaty are sufficiently clear and precise (the typical wording in this respect is "self executing") the victim can call directly on these provisions even if the State would have failed to take

\footnotetext{
${ }^{8}$ For details on nuclear liability see inter alia Degros, Ch., "La responsabilité civile nucléaire: un état des lieux", in Viney, G. and Dubuisson, B. (eds.), Les responsabilités environnementales dans l'espace Européen. Point de vue franco-belge, Brussels, Bruylant, 2006, 303-374 and Vanden Borre, T., 'Shifts in governance in compensation for nuclear damage, 20 years after Chernobyl', in Faure, M. and Verheij, A. (eds.), Shifts in Compensation for Environmental Damage, Vienna, Springer, 2007, 261-311.
} 
measures in national law to implement the obligations. This is not true in legal systems that have a so-called dualistic approach (such as e.g. Germany). In those systems, citizens do not have the possibility to call directly on international law as long as it has not been transposed into national law. Hence, in this dualistic approach, first national transposing legislation is necessary on which the citizen can subsequently call.

\subsection{Tchernobyl Case: District Court of Bonn}

This is of course the well-known standard theory of international law concerning the relationship between individuals and international law. ${ }^{9}$ More interesting is the question whether a victim could also call on international law if it has been violated by a polluter State. Suppose that a convention (or obligation of international customary law) would oblige States to warn neighbouring States and their citizens if a major nuclear incident took place as a result of which a nuclear cloud could come in the direction of the neighbours, necessitating preventive measures (e.g. putting cattle in the stables) in the neighbouring States. Could a victim in the neighbouring State call on the liability of the polluter State if this obligation would be violated and the victim suffered harm as a result of this? This was the question that had to be answered by the civil court of first instance of Bonn in a claim filed by a gardener in Germany against the Soviet Union who argued that the Soviet Union had violated its obligation of early notification. ${ }^{10}$ The German court held, not surprisingly, that there is no direct liability of the Soviet Union vis-à-vis the German gardener. If the Soviet Union would have had an obligation under international law to notify Germany and would not have done so, this could only have amounted to liability under international law of the Soviet Union visà-vis Germany. The German court therefore adhered to the classic view that international norms cannot be called upon by one individual in a victim State to hold a polluter State liable. $^{11}$

\footnotetext{
${ }^{9}$ See generally (in Dutch), Nollkaemper, P.A. et al., De nationale rechter en het internationale recht, Den Haag, Mededelingen NVIR 131, 2005, preadviezen.

${ }^{10}$ See a discussion of this decision of 29 September 1987 by Rest, A., "International Environmental Law before German Courts”, Tijdschrift voor Milieuaansprakelijkheid (Environmental Liability Review), 1997, 116 at p. 121-122 and Nollkaemper, P.A., "How Public International (Environmental) Law can furnish a Rule of Decision in Civil Litigation”, Tijdschrift voor Milieuaansprakelijkheid (Environmental Liability Review), 1998, 3-4.

${ }^{11}$ Nollkaemper adds that this a forciori means that if the German farmer would not have sued the Soviet Union but the private corporation in the Soviet Union liable for the nuclear cloud: the principle of notification would then certainly also not have had any effects between two individuals (Nollkaemper, P.A., supra note 10, at 3).
} 


\subsection{MDPA Case: Direct Application of International Law}

Nevertheless, there can be situations where norms of international law do clearly play a role in transboundary liability suits. ${ }^{12}$ This is the moment to introduce one of the first Dutch cases concerning transboundary pollution. It considers the case launched by various gardeners in the Netherlands in the 1970s against the Mine de Potace d'Alsace (MDPA). The market gardeners held that MDPA by discharging salt in the Rhine increased the salt burden of the water of the Rhine to such an extent that they could not make use any more of the water of the Rhine and hence suffered damage as a result of it. This MDPA case has been extensively discussed in the literature ${ }^{13}$ and has given rise to many judgments, even of the supreme court of the Netherlands. ${ }^{14}$ The cases are inter alia interesting since under two different headings, the relationship between international law and the rights of individuals suffering harm are discussed. The most far reaching approach ${ }^{15}$ was provided by the district court of Rotterdam handling the case in first instance. ${ }^{16}$ The district court of Rotterdam held that since, no rule of national law could be found to decide this case, it had to turn to unwritten international law and applied the principle that no State can use its territory for activities that cause harm to another State. The district court of Rotterdam thereby explicitly refers to the well-known Trail Smelter case which made this so-called good neighbourliness principle explicit. ${ }^{17}$ The court of appeals of The Hague, however, reversed this ruling. ${ }^{18}$ The court held that direct effects of rules of international law applied exclusively to treaties and not to unwritten rules of

\footnotetext{
${ }^{12}$ For a detailed discussion of this see the already mentioned contribution of Nollkaemper, P.A., supra note 10.

${ }^{13}$ See inter alia Betlem, G. (1993), supra note 6, 393-401 and the contributions in Van Dunné, J.M. (ed.), Transboundary Pollution and Liability: the Case of the River Rhine, Vermande, Lelystad, 1991.

${ }^{14}$ Supreme Court of the Netherlands, 23 September 1988, Tijdschrift voor Milieuaansprakelijkheid (Environmental Liability Review), 1989, 15-18.

${ }^{15}$ According to Nollkaemper, P.A., supra note 10, at 6-7.

${ }^{16}$ Handelskwekerij G.J. Bier B.V. and Stichting Reinwater v. de Potace d'Alsace sa (MDPA), district court of Rotterdam NJ 1979, 113, Netherlands Yearbook of International Law, 1980, vol. 11, 326 and district court of Rotterdam, 16 December 1983, NJ 1984, 341, Netherlands Yearbook of International Law, 1984, vol. 15, 471.

${ }^{17}$ Trail Smelter Arbitration Tribunal (U.S. v. Canada), 33 AJIL 182 (1939) and 35 AJIL 684 (1941); see generally Bratspies, R.M. and Miller, R.A. (eds.), Transboundary Harm in International Law: Lessons from the Trail Smelter Arbitration, Cambridge, CUP, 2006 and Sands, Ph., Principles of International Environmental Law, ${ }^{\text {nd }}$ ed., Cambridge, Cambridge University Press, 2003, 241-242 and 318-319.

${ }^{18}$ Court of Appeals of the Hague, 10 September 1986, Tijdschrift voor Milieuaansprakelijkheid (Environmental Liability Review) 1987, 15 with case note by Vandermeer, Netherlands Yearbook of International Law, 1988, vol. 19, 496.
} 
international law. Nollkaemper, however, holds that general principles of law can also satisfy the "self executing test" and that, moreover, these general principles often find their origin in national law, where they do generally apply to individuals. He therefore concludes that the court of appeals
"did not expressly overrule (nor did it need to do so) the part of the judgment that sanctioned violation of the norm on the basis of international law. To that extent, this construction of direct application and enforcement of international law can still be said to exist in Dutch law". ${ }^{19}$

The MDPA case discusses another interesting aspect of the relationship between international law and national liability law. The attorney of the defendant held that the lawfulness of the emissions by MDPA had to be seen in the light of a so-called Bonn Salt Treaty. ${ }^{20}$ The defendant argued inter alia that now that the Netherlands and France have acceded to the Treaty, which explicitly aims at reducing transborder pollution of the Rhine to acceptable levels for Dutch users, the Dutch gardeners cannot reproach MDPA to have acted in excess of emission levels laid down in the particular Treaty. The argument of MDPA hence was that this international Treaty between France and the Netherlands would bar a claim in tort since the Treaty would deal with the issue of the salt discharges from France into the Rhine in a final way. The Hoge Raad explicitly discusses this argument and rejects it on the following grounds:

\begin{abstract}
"The argument of the count cannot be accepted as correct. Leaving aside that fact that the Treaty only became operative in 1985, while damages in this action are demanded as from 1974, it follows from the text and the purport of the Treaty that it only intends to impose obligations on the States that enter into the Treaty. There is no indication at all that the Treaty - which came into being when the action in question was already running - should also have in view the regulation of the internal relations of the subjects of that States entering into the Treaty, nor also that in this manner the judge in one of these States should be held to have to decide an action between those subjects on the basis of the Treaty".
\end{abstract}

\footnotetext{
${ }^{19}$ See Nollkaemper, P.A., supra note 10 at 4, footnote 10 . The supreme court did not express itself on this particular issue.

${ }^{20}$ An agreement of 3 December 1976 concerning the protection of the Rhine against pollution by chloride.
} 
The supreme court held in other words that the Treaty was not relevant for determining the wrongfulness of the discharges by the French defendant since the Treaty would only cover the relationship between the States which are party to the Treaty and not between private persons. $^{21}$

\subsection{Lessons}

The lesson from this legal doctrine and case law seems to be that individuals can indeed not directly call on a violation of norms of international law by another State (district court of Bonn) but at least some case law basis liability in tort of a foreign polluter on a violation of international law (district court of Rotterdam). Moreover, since treaties in principle only govern the relationship between States, compliance with a Treaty by the polluter State does not necessarily have a justificatory effect for individual polluters (Supreme Court in the MDPA case). Moreover, even though the decision of the district court of Rotterdam whereby an individual polluter was basically held directly liable for violating international law may be debated, international law can of course play another role in transboundary pollution disputes between individuals: it can be used as an aid to interpret open norms in national law. ${ }^{22}$ In this respect, it should not be forgotten that the basic norm of tort law in many legal systems is today still rather open-textured and requires for example that a defendant behaved with “reasonable care”. In interpreting whether, in a transboundary pollution case, a defendant took reasonable care, a judge could also consider whether Treaty obligations or unwritten norms of international law have been violated. Even though the defendant would then not be held directly liable for violating international law, the norms of international law can assist in making vague obligations under national tort law more specific and concrete. ${ }^{23}$

Finally in this section, and as noted above, the most famous case about transboundary

\footnotetext{
${ }^{21}$ Nollkaemper rightly argues that this opinion can have very far reaching consequences since in this way a Dutch judge could theoretically prohibit all discharges from France and could thus disregard the rights of France under international law on the basis of a Treaty. Nollkaemper considers it doubtful whether the Hoge Raad intended such a radical gap between international and domestic law. (Nollkaemper, P.A., supra note 10 at 8).

${ }^{22}$ Nollkaemper, P.A., supra note 10 at 9 .

${ }^{23}$ That is hence different than what the district court of Rotterdam did who held the French defendant liable because the company had violated a norm of international law.
} 
pollution in public international law is Trail Smelter. ${ }^{24}$ It concerns a Canadian lead-zinc smelter in Trail, British Columbia, close to the US border with the State of Washington, causing environmental damage in the latter as a result of air pollution. Arbitration at the interState level took place and the principles of international law about States' obligations to prevent transboundary harm were clarified. States must not use or permit the use of their territory where serious injury is caused to another State in breach of its obligations; the source State is responsible in international law in damages and must prevent future damage. ${ }^{25}$ In terms of lesson to be learned, Knox argues that the international level dispute resolution is exactly how not to deal with a dispute like this. ${ }^{26}$ Noting that no other similar tribunals have been set up since, he puts it in no uncertain terms: Trail Smelter was a case before a wrong tribunal, between wrong parties, applying the wrong law. Instead of an international body, a national court should be used, primarily applying domestic and not international law, by private litigants rather than States. In the remainder of this paper we will examine precisely such a scenario of private litigation before civil courts and the legal issues which will have to be addressed.

\section{Forum}

\subsection{Importance}

A crucial and often decisive issue in transboundary pollution cases is where a liability suit can be brought. For victims, it will of course usually be far more attractive to bring a liability suit before their own courts. Intuitively, one can understand why this would be the case. First of all, there is a simple argument of costs: when the victim would have to sue a polluter in the polluter State, he would probably need to seek counsel in the polluter State, would have to make costs of travel etc., which can be substantially higher than when a suit can be brought in the place where the harm is suffered by the victim. Second, the choice of jurisdiction will often also have a decisive influence on the choice of law. It will usually be the lex fori that will determine the rules of international private law. Having the possibility to sue in the victim State will hence often result in the application of the victim's national law and the

\footnotetext{
${ }^{24}$ Trail Smelter Arbitration Tribunal (U.S. v. Canada), 33 AJIL 182 (1939) and 35 AJIL 684 (1941); see generally Bratspies, R.M. (ed.), Transboundary Harm in International Law: Lessons from the Trail Smelter Arbitration, Cambridge, CUP, 2006.

${ }^{25}$ Birnie, P.W. and Boyle, A., supra note 7, 504-505.

${ }^{26}$ Knox, J.H., "The Flawed Trail Smelter Procedure: The Wrong Tribunal, the Wrong Parties and the Wrong law," in Bratspies, R.M. and Miller, R.A. (eds.), Transboundary Harm in International Law: Lessons from the Trail Smelter Arbitration, Cambridge, CUP, 2006, 66-78.
} 
reverse may be the case when the victim has to sue in the polluter State. The latter issue is of course crucially related to a third element: one can expect the judiciary in the victim State to be far more sympathetic towards the case of the victim than the judiciary in the polluter State. This has all to do with the issues mentioned in the introduction: even if in most European States judges are not elected, but professional appointed judges, a judge in a polluter State may, far away from where the harm occurred, have more sympathy for the difficulties that a polluter has in applying (costly) pollution reducing measures and may fear negative socioeconomic consequences of liability cases and vice versa: a judge in the victim State will primarily be concerned with the harm suffered on his territory and be less inclined to worry about socio-economic consequences of a finding of liability in the polluter State. That is why the potential success of transboundary pollution cases will often depend upon the possibility for the victim to bring a claim in his own State. Of course, this is crucially related to the second question, being whether if the victim would have obtained a positive judgment, he can subsequently obtain a recognition and enforcement in the polluter State. If that would not be the case starting legal proceedings in a victim State would be pointless. This issue of jurisdiction is therefore crucially related to the issue of recognition and enforcement. ${ }^{27}$

\subsection{Brussels Convention}

There is abundant literature on jurisdiction issues in international conflicts, which goes far beyond the limited scope of this contribution. We should, however, remember that a common and universally accepted jurisdiction ground is the so-called forum rei: the place of the defendant's domicile. The main argument for it is the protection of the defendant. Since the defendant did not start the proceedings, he should not be forced to go abroad and defend himself. The opposite, the place of domicile of the plaintiff (forum actoris) is therefore rather the exception. ${ }^{28}$ The result is that to constitute a rule of jurisdiction which allows a plaintiff to bring a claim in the State where the harm occurred will usually need an explicit legal basis in a convention. Within the European context for a long time the relevant convention was the Brussels Convention of 27 September 1968 on jurisdiction and the enforcement of judgments in civil and commercial matters. This document provided the context for deciding the

\footnotetext{
${ }^{27}$ Which we will discuss below in section 9.

${ }^{28}$ See for a global overview the Final and Second Report of the International Law Association's Committee on Transnational Enforcement of International Environmental Law, available online at: $<$ http://www.ila-hq.org/html/layout_committee.htm>.
} 
jurisdiction in a few of the Dutch cases which we provide a central place in this contribution, but of course in other continents other bilateral or multilateral treaties with the same goal (providing rules on jurisdictions) apply. We will not, within the scope of this contribution, discuss the details of the Brussels convention ${ }^{29}$ but we will briefly discuss the instrument that determines jurisdiction and recognition today in the European Union and subsequently discuss how the forum issue was decided in some of our Dutch cases.

\subsection{Council Regulation 44/2001}

Today, jurisdiction issues in the European Union are dealt with by Council Regulation 44/2001 of 22 December 2000 on jurisdiction and the recognition and enforcement of judgments in civil and commercial matters. ${ }^{30}$ It applies to all current 27 Member States, including Denmark, by international Agreement between the European Community and the Kingdom of Denmark, as a matter of international law. ${ }^{31}$ In general terms, we are concerned here with the harmonised rules on civil jurisdiction and the recognition and enforcement of judgments in civil cases shared by the Member States of the European Union; hereinafter we shall refer to them as the Brussels I regime (or simply Brussels I, comprising the case law of the European Court of Justice (ECJ) under the Convention which remains relevant for most provisions of the current Regulation). The main rule of jurisdiction of the civil courts under this Brussels I regime is the defendant's domicile, the cited forum rei (Art. 2). However, this Regulation has also, as far as relevant for our transboundary pollution case, retaken Article 5(3) of Brussels I which provides that a person domiciled in a Member State may, in another Member State be sued "in matters relating to tort, delict or quasi-delict, in the courts for the place where the harmful event occurred or may occur”. Since pollution cases are of course usually cases of non-contractual liability, this rule could provide victim courts with jurisdiction over transboundary pollution cases. However, the problem is that the expression "place where the harmful event occurred" in Article 5(3) is ambiguous. It is not clear whether this refers to the place where the damage occurs (the so-called Erfolgsort) or the place where

\footnotetext{
${ }^{29}$ For a detailed discussion and the relevance for transboundary pollution cases, see the dissertation of Betlem, G. (1993), supra note 6, 23-166.

${ }^{30} \mathrm{OJ}$ L12/1 of 16 January 2001.

${ }^{31}$ OJ L299/62 of 16 November 2005. Approved by Council Decision 2006/325/EC of 27 April 2006 concerning the conclusion of the Agreement between the European Community and the Kingdom of Denmark on jurisdiction and the recognition and enforcement of judgments in civil and commercial matters; not yet published in the OJ 2006 L120/22. Ratified by Denmark on 18 January 2007; entry into force: 1 July 2007; see <ec.europa.eu/civiljustice/news/whatsnew_en.htm>.
} 
the emission took place (the so-called Handlungsort) or to both. This problem arose also in the already discussed case of the Dutch gardeners against the French potassium mines. Uncertainty arose concerning the interpretation of Article 5(3) since the district court of Rotterdam in a first judgment held that it had no jurisdiction, because, in its view, Article 5(3) only creates jurisdiction for the courts of the place where the emission took place. ${ }^{32}$ The latter would have meant that the victims could only bring a claim in France. On appeal, the court of appeals of The Hague referred the question of the interpretation of this provision to the European court of justice. The court ruled as follows in its meanwhile well-known ruling in the Bier case: ${ }^{33}$

"Where the place of the happening of the event which may give raise to liability in tort, delict or quasi-delict and the place where that event results in damage are not identical, the expression "place where the harmful event occurred" in Article 5(3) of the Convention (...) must be understood as being intended to cover both the place where the damage occurred and the place of the event giving raise to it. The result is that the defendant may be sued, at the option of the plaintiff, either in the courts for the place where the damage occurred or in the court for the place of the event which gives raise to and is at the origin of that damage".

The major advantage for victims of transboundary pollution in the European context is hence that they can bring a suit in their own State against foreign polluters who are based in another EU Member State. ${ }^{34}$ As a matter of Community law, it is up to plaintiffs to decide where to bring the case: they have the option to sue at the place of domicile of the defendant, the place of impact of the pollution (normally the plaintiff's home State) or the place of emission. The same applies, under current Dutch law, where a defendant based outside the EU is sued before a Dutch court. ${ }^{35}$

The issue of jurisdiction was also litigated in a second Dutch case of an environmental nongovernmental organization (Reinwater) against a Belgian polluter (Sopar). The plaintiffs

\footnotetext{
${ }^{32}$ District court of Rotterdam, 12 May 1975, Netherlands Yearbook of International Law, 1976, vol. 7, 344, Netherlands International Law Review, 1975, 203 with case note by Verheul.

${ }^{33}$ Case 21/76 Bier v. Mine de Potace d'Alsace,[1976] ECR 1735, 1748-1749.

${ }^{34}$ For a more detailed discussion of the consequences and reasoning in this Bier decision of the ECJ see Betlem, G. (1993), supra note 6, 92 and following and see Betlem, G. (1993), supra note 6, 146149.

${ }^{35}$ See Strikwerda, L., Inleiding tot het Nederlandse internationaal privaatrecht, 8th ed., Deventer, Kluwer, 2005, No. 217.
} 
demanded an injunction against Sopar to discontinue or at least limit the discharge of PAHs, (polycyclic aromatic hydrocarbons), on the basis of best available technical means. The NGO asserted that Sopar's discharges into the Gent-Terneuzen canal, just over the Dutch border constituted a wrongful act. ${ }^{36}$ Interestingly, in terms of jurisdiction, the President of the Court of Middelburg recognised the court's competence on the basis of Article 5(3) of the Brussels Convention. Moreover, the case is also decided by the court of appeals of the Hague. ${ }^{37}$ There, it is also noticed that in fact the defendant Sopar did not object at all to the jurisdiction of the Dutch courts. In that particular case, Article 18 of the Brussels Convention was applied, which holds that a court also has jurisdiction simply if a defendant enters an appearance without contesting the jurisdiction. ${ }^{38}$

In addition, the Brussels I Regulation attributes competence "as regards a dispute arising out of the operations of a branch, agency or other establishment", to "the courts for the place in which the branch, agency or other establishment is situated” (Article 5(5)). The key aspect of this provision is that another entity than the branch itself can be sued before the courts of the location of the branch. In the main that would be the parent company of the branch if the latter is a separate legal person. ${ }^{39}$ If the branch is not an independent legal person it could not be sued at all and the result of this provision is that the legal entity constituting the corporation may be sued not only at its own seat but at the place of the branch as well. The provision is only applicable at all with respect to a branch of a company itself domiciled within the EU; it therefore cannot be used with respect to a branch of e.g. an American company. ${ }^{40}$

\footnotetext{
${ }^{36}$ First Instance: President of the court of Middelburg, 8 March 1991, Tijdschrift voor Milieuaansprakelijkheid (Environmental Liability Review), 22 with case note by Frenk, Milieu \& Recht, 1991, 357 with case note by Betlem; Nederlands Internationaal Privaatrecht 1991, 172. Appeal: Hof Den Haag 19 November 1992, Kort Geding 1993, 15; TMA 1993, 131 note by De Vries; NIPR 1993, 115.

${ }^{37}$ Court of appeals of the Hague, 19 November 1992, Tijdschrift voor Milieuaansprakelijkheid (Environmental Liability Review), 1993, 132 with case note by L.J.A. De Vries; [Belgian] Tijdschrift voor Milieurecht 1993-3, 153 note by Faure. The defendant's appeal in cassation was unsuccessful, see Dutch Supreme Court: HR 25 February 1994, NJ 1996, 362 (Rütgers/Sopar v. Stichting Reinwater et al.).

${ }^{38}$ The same rule is now contained in article 24 of council regulation 44/2001 and reads: "Apart from jurisdiction derived from other provisions of this regulation, a court of a member State before which a defendant enters an appearance shall have jurisdiction. This rule shall not apply where appearance was entered to contest the jurisdiction, or where another court has exclusive jurisdiction by virtue of article 22".

${ }^{39}$ Cf. Case 218/86 Schotte v. Rothschild [1987] ECR 4905 holding that an independent company within a group may constitute a branch for the purpose of jurisdiction; remarkably, the "branch" was sued at the place of the parent.

${ }^{40}$ This follows from the first line of Article 5(5) itself, which reads: "A person domiciled in a
} 
Where this provision is applicable, it is limited to disputes concerning the operations of the branch. This notion has been construed by the ECJ in the Somafer case to encompass both contractual and non-contractual obligations "arising from the activities in which the branch (...) has engaged at the place in which it is established on behalf of the parent body". ${ }^{41}$ The Court circumscribed the activities as pertaining to the management properly so-called of the branch, such as the State of the building, the engagement of staff, or contracts entered into at the place of the branch which must be performed within the same Contracting State. This interpretation has been criticised in the literature and by an Advocate General for being unduly restrictive as it would seem to limit this forum to acts (including their impact) within the forum State. ${ }^{42}$

However, in the subsequent case of Llyod's Register the ECJ made it clear that there is no such a geographical limitation to Article 5(5). This judgment concerned contractual obligations, entered into in France between a French company and the French branch of the London based Lloyd's Register of Shipping, which were to be performed in Spain. The ECJ did not accept the argument that the rule of the forum of the branch requires a limitation to performance within the State of the branch. Instead, it held that were the branch forum to be restricted to performance of obligations within the State of the branch, this rule would be rendered almost redundant in the light of Article 5(1) which already allows the plaintiff to sue before the courts of the place of performance of the obligation. ${ }^{43}$ The ruling substantially increases the added value of the forum of the branch compared to Somafer. The same reasoning applies to non-contractual obligations. ${ }^{44}$

Accordingly, the Brussels I jurisdiction regime recognises a limited form of forum selection purely at the behest of the plaintiff. It may be added here that there may be circumstances, e.g. particular procedural mechanisms only available there, where the forum of the defendant's domicile is selected. If so, it is important to note that the courts of that State must take jurisdiction over the defendant under Article 2 Brussels I. There has never been any doubt about the mandatory nature of that rule with respect to civil law countries such as the Netherlands. However, under English law, a court does not have to exercise its jurisdiction if another court elsewhere is better placed to deal with the dispute under the doctrine of forum

Contracting State may, in another Contracting State, be sued: ... [emphasis added]”.

${ }^{41}$ Case 33/78 Somafer v. Saar-Ferngas [1978] ECR 2183 at 2194.

42 Opinion of A-G Elmer in Case C-439/93 Lloyd's Register [1995] ECR I-961, No. 7.

${ }^{43}$ Case C-439/93 Lloyd's Register [1995] ECR I-961, para. 17.

${ }^{44}$ See the Opinion of A-G Elmer at No. 8 and the English Court of Appeal, in the context of the parallel instrument to Brussels I, the Lugano Convention: Durbeck v. Den Norske Bank [2003] Q.B. 1160 (Re Tropical Reefer). 
non conveniens. ${ }^{45}$ Unlike the courts in civil law jurisdictions, English (and other common law) courts possess inherent discretionary powers to stay an action commenced by a claimant before it when the defendant is able to persuade the court that an injustice would be done to him because the English court is an inappropriate forum and there is a better forum elsewhere. ${ }^{46}$ There was uncertainty whether the mandatory nature - as opposed to the cited discretionary powers of the English courts under their own rules of jurisdiction - of the forum of the domicile under the Brussels I regime was restricted to intra-Community cases or not. In Owusu, ${ }^{47}$ the ECJ held that Article 2 is mandatory and applies in all situations where the defendant is domiciled in England even where the relationship with a court outside the EU might be in issue under the doctrine of forum non conveniens. It ruled that:

"35. ... Article 2 of the Brussels Convention applies to circumstances such as those in the
main proceedings, involving relationships between the courts of a single Contracting State and those of a non-Contracting State rather than relationships between the courts of a number of Contracting States. ...

Moreover, allowing forum non conveniens in the context of the Brussels Convention would be likely to affect the uniform application of the rules of jurisdiction contained therein in so far as that doctrine is recognised only in a limited number of Contracting States, whereas the objective of the Brussels Convention is precisely to lay down common rules to the exclusion of derogating national rules. “

Accordingly, also English courts must now accept the mandatory nature of Article 2 (forum rei) in all situations falling within the scope of Brussels I and involving a defendant domiciled in England. In other words, the doctrine of forum non conveniens cannot be applied by an English court when its jurisdiction over the defendant flows from Article 2 Brussels I. This holds true even where the claimant is domiciled outside the EU. The domicile of the claimant is completely irrelevant in this regard. After Owusu, it is now a thing of the past for a situation to occur of completely different treatment of two sets of civil actions against the same

\footnotetext{
${ }^{45}$ See for more details the Second Report by the International Law Association's Committee on Transnational Enforcement of International Environmental Law for the August 2004 biannual Conference in Berlin, supra note 28 and Briggs, A., The Conflict of Laws, Oxford, OUP, 2002, 94.

${ }^{46}$ McClean, D. \& Beevers, K., Morris: The Conflict of Laws, ${ }^{\text {th }}$ ed. ( London: Sweet \& Maxwell 2005), p. 120.

${ }^{47}$ Case C-281/02, [2005] ECR I-1383 (judgment of 1 March 2005); [2005] I.L.Pr. 25.
} 
England-domiciled defendant as, for example, took place in Lubbe v. Cape, ${ }^{48}$ where one group of plaintiffs was based in an EU Member State and another in a third country. The defendant Cape was able to invoke forum non coveniens (albeit ultimately unsuccessfully) against South-African domiciled claimants but not against those domiciled in Italy. In Lubbe, the House of Lords recognised that a stay of proceedings under the doctrine of forum non conveniens would only be possible where Article 2 of Brussels I would not apply. Essentially the same question as in Owusu was debated but because the House of Lords had already decided not to grant a stay it was not necessary in Lubbe to refer the matter to the ECJ. In the post-Owusu era we now know for certain that all plaintiffs - whether based inside or outside the EU - will be able to rely on Article 2 of Brussels I to sue an operator domiciled in England. ${ }^{49}$

Finally on jurisdiction, nothing detracts from the above noted forum selection opportunities where damage to land is in issue. That is to say that tort based claims do not come within the ambit of the exclusive jurisdiction rule of the Brussels I Regulation dealing with rights in rem in immoveable property (Article 22(1) Brussels I Regulation; Art. 16(1) Brussels Convention). It had already been argued in the literature that a tort based claim should not be characterised as coming within the scope of "rights in rem" within the meaning of this provision, ${ }^{50}$ uncertainty remained, however, until the 2006 ECJ ruling in CEZ. ${ }^{51}$ The case concerns an application for injunctive relief to an Austrian court by a local authority of Austria, the Land Oberösterreich, against the Czech operator of a nuclear power station (CEZ) based in the Czech Republic not far from the border. The plaintiff alleged that the operator caused a nuisance by its radioactive emissions and sought to restrain it; it took the action in its capacity as owner of agricultural land, i.e. not as a public authority as such. CEZ relied on the exclusive jurisdiction rule for immoveable property to argue, ingeniously, that the Austrian court had no jurisdiction under the Brussels I regime. At that time, the Czech Republic was not yet an EU Member State and it was no party to the Brussels Convention. In its view, the only possible ground for jurisdiction of the Austrian court could then only be

\footnotetext{
${ }^{48}$ [2000] 1 W.L.R. 1545; [2000] 4 All ER 268; [2001] I.L.Pr. 140.

${ }^{49}$ See for the possibility to nevertheless invoke forum non conveniens or issue an anti-suit injunction when there are either arbitration or exclusive jurisdiction clauses: Through Transport Mutual Insurance Association (Eurasia) Ltd v New India Assurance Co Ltd (The Hari Bhum), [2004] EWCA Civ 1598, [2005] I.L.Pr. 30 (CA), case note Merret in [2005] C.L.J. 308; West Tankers v. Ras Riunione Adriatica di Sicurta, sub nom The Front Comor [2005] EWHC 454 (Comm); after a leap frog appeal to the House of Lords, the latter case is now pending before the ECJ, see Case C-185/07, OJ 2007 C 155/9.

${ }^{50}$ E.g. by Betlem (1993), supra note 6, 141-144.

${ }^{51}$ Case C-343/04, [2006] ECR I-4557 (judgment of 18 May 2006), [2006] I.L.Pr. 25.
} 
Article 16(1) as it applies regardless of the domicile of the defendant. If this provision were to

apply, no other basis of jurisdiction may be relied upon, even parallel rules of domestic law, ${ }^{52}$ as that would undermine the operation of the Brussels I regime. However, it also took the view that that provision did not cover tort based claims in nuisance so that it too could not be used to found the jurisdiction of the Austrian court.

Contrary to the Opinion of Advocate General Poiares Maduro, the ECJ followed a well-established line of authorities which adopts a restrictive interpretation of the immoveable property exclusive jurisdiction. It noted that Article 16 deprives parties of any choices of forum and could even have the effect of a court having exclusive jurisdiction of none of the parties’ domicile (para. 27). The Court further refers to the objectives of the exclusive jurisdiction, in short: relevance of land registry and proximity of court for proper administration of justice. It ruled that "an action which (...) seeks to prevent a nuisance affecting or likely to affect land belonging to the applicant, caused by ionising radiation emanating from a nuclear power station situated on the territory of a neighbouring State to that in which the land is situated, does not fall within the scope of [Article 16(1)]" (para. 40).

Accordingly, it is now clear that tort based claims dealing with land are not caught by the exclusive jurisdiction of Brussels I for rights in rem in immoveable property. The full choice of forum under Articles 2 and 5(3) remains available. ${ }^{53}$

\section{Applicable law}

\subsection{Dutch law}

The question of which law will govern the dispute, had been in issue in the two Dutch cases we already discussed. Once it has been established that a Dutch court is competent to adjudicate the transnational dispute the question arises - given the international character of the case - what law this court will apply: Dutch or foreign (tort) law? Potentially complex litigation about this issue may be prevented by a choice of law by the parties. This may be in the interest of both parties, including the non-Dutch based one, as application of foreign law is not reviewable before the Dutch Supreme Court. For that reason, i.e. to enable him to enjoy the full benefits of litigation in three instances, the French defendant in the French potassium

\footnotetext{
${ }^{52}$ See Opinion of A-G Poiares Maduro in CEZ, No. 24.

${ }^{53}$ It is beyond the scope of this contribution to examine even further options for plaintiffs notably under the rules for provisional measures, see Art. 31 of the Regulation and in particular Case C-391/95 Van Uden Maritime [1998] ECR I-7091 as well as Case C-99/96 Mietz [1999] ECR I2277. See generally Stone, P., EU Private International Law, Cheltenham/Northampton, Edward Elgar, 2006, Ch. 9.
} 
mines litigation about pollution of the river Rhine opted for a choice of Dutch law. In its first (interlocutory) judgment on the merits, the district court of Rotterdam decided as follows: ${ }^{54}$

"concerning the applicable law:

the plaintiffs regard their actions as being governed by Dutch law, whereas MDPA in principle prefers the dispute to be adjudged by French law but agreed at the hearing that the court shall apply Dutch law, because - if French law were to be applied - the misapplication of foreign law by the lower courts could not be pleaded in cassation; the court acknowledges this subsequent choice of law "as a choice of current Dutch law"."

Here one can hence notice the acceptance of party autonomy with respect to applicable tort law: if all parties agree that Dutch law applies, this will be accepted by the court.

Also in the already mentioned Sopar case, an interesting issue concerning applicable law arose. Even though it was not discussed in much detail, the question whether there was unlawfulness was apparently decided on the basis of Dutch law by the Dutch courts (district court of Middelburg and court of appeals of The Hague). ${ }^{55}$ However, the plaintiff (the NGO Reinwater) had also reproached Sopar that the discharge permit it had would not have been legal. In that respect, the court of appeals holds: "The Belgian discharge permit (of which for the moment it has to be accepted that it is valid according to Belgian law) can not in a summary proceedings be tested by a Dutch judge according to Dutch norms, unless there would be a violation of international norms, which has not appeared in this particular case”.

The judge seems to suggest that although Dutch tort law applies, in judging whether the Belgian discharge permit was lawful, the Belgian norms of administrative law apply. Another issue is of course whether following the conditions of a foreign licence has a justificatory effect in tort. That is, however, a substantive issue of tort law (which regards the unlawfulness) rather than an issue of applicable law and will be further examined below. ${ }^{56}$

As for the current position on choice of law in cross-border pollution case and more generally, mention should be made of the recent codification of these rules by the Dutch

\footnotetext{
${ }^{54}$ District court of Rotterdam, 8 January 1979, Netherlands Yearbook of International Law 1980, vol. 11, 326, Netherlands International Law Review, 1981, 63 with case note by Duintjer Tebbens, Nederlandse Jurisprudentie, 1979, 113, Ars Aequi, 1980, 788 with case note by D’Olivera.

${ }^{55}$ Since it concerns a summary proceedings, the judgment did not refer explicitly to the choice of law issue. See Betlem, G. (1993), supra note 6, 174.

${ }^{56}$ So Betlem, G. (1993), supra note 6, 178-182.
} 
legislature, including a choice of law by the parties. ${ }^{57}$ Absent a choice of law, the rule with which the law governing the dispute is selected is the lex loci delicti: the law of the place where the tort occurs. ${ }^{58}$ This rule is relatively straight forward where an event occurs at a place where it also causes the loss, such as traffic accidents. However, application of this rule is problematic when more than one locus may qualify as the place of the harmful event. In cases where the actual injury occurs in another country than the one where the act causing this damage took place (a `distance delict') such a situation obtains. ${ }^{59}$ Just like in the context of jurisdiction, both these places might qualify; we have already seen that the ECJ has, under the Brussels Convention, ruled to the effect that the plaintiff can choose between the court of the place of the wrongful activity and the court of the place where the loss occurred. ${ }^{60}$ To date, there is no case law of the supreme court of the Netherlands (the Hoge Raad) on this issue.

However, the cited codification of the Dutch choice of law rules for tort was used by the legislature to clarify certain matters, including the problem of localising the locus delciti in multiple locality situations. The relevant rules read as follows:

\section{“Article 3}

Obligations arising from a tort shall be governed by the law of the State, within which the act took place.

In derogation to section 1, when the act produces a harmful impact on a person, property or the environment in a State other than the one within which the act occurred, the applicable law shall be the law of the State where the impact occurs, unless the tortfeasor could not reasonably have foreseen such impact."

Section 1 lays down the main lex loci delicti rule whereas Section 2 provides a solution to the choice of locus issue. Or, in the terminology used above, in the context of jurisdiction, Section 1 refers the place where the emission took place (the so-called Handlungsort) whilst Section 2 refers to the place where the damage occurs (the so-called Erfolgsort). Although the

\footnotetext{
${ }^{57}$ See Tort - Choice of Law Act 1999 (Wet Conflictenrecht Onrechtmatige Daad, Stb. 2001,190 , see $<$ www.overheid.nl/op>); Strikwerda, L., supra note 35, No. 180.

${ }^{58}$ HR 19 November 1993, NJ 1994, 622 (COVA); NILR 1994, p. 363.

${ }^{59}$ Opinion of A-G Strikwerda in HR 9 December 1988, NJ 1989, 203 (Kanthai and Kanthai/Vardinoyannis), No. 3.8.

${ }^{60}$ Case 21/76 Bier v. MDPA [1976] ECR 1735; NJ 1977, 94. Subsequent case law has introduced certain restrictions, see Case C-220/88 Dumez France and Tracoba [1990] ECR I-49, NJ 1991, 573; Case C-68/93 Shevill [1995] ECR I-415, NJ 1996, 269; Case C-364/93 Marinari [1995] ECR I-2719; NJ 1997, 52 and Case C-51/97 Réunion européenne [1998] ECR I-6511 (judgment of 27 October 1998).
} 
environment is specifically mentioned and the legislature's choice was mainly based on the compensatory function of the law of tort, there is a qualification in terms of an unforeseeability exception. ${ }^{61}$ Since this might be called an exception to the exception, application of it leads us back to the main rule: the law of the place where the act took place.

In conclusion, the current Dutch statutory rule on the applicable law for torts in the absence of a bilateral choice by the patties is a particular manifestation of the lex loci delcti, namely the so-called Handlungsort, or place where the tortfeasor has acted. As will be seen in the next paragraphs, this approach is going to be short-lived as the Dutch law will soon be replaced by yet another EU Regulation.

\subsection{EU law: Rome II update}

An important development at EU level is the adoption of the so-called Rome II Regulation in July 2007. ${ }^{62}$ Like the Brussels I Regulation discussed above (para. 3.3), Rome II is also a Regulation within the meaning of Article 249 of the EC Treaty. ${ }^{63}$ It is a directly applicable instrument of secondary Community law, which will replace most of the Member States' choice of law rules in the field of tort law from the $11^{\text {th }}$ of January 2009. In EU jargon, $t$ is called “Rome II," because it is a complement to an existing instrument - Rome I - in the field of the choice of law rules regarding contractual obligations. ${ }^{64}$ The new legislation harmonises, within its substantive scope which does not cover defamation and privacy claims, the conflict of law rules pertaining to non-contractual obligations and contains both general and specific rules as well as allowing the parties to select the applicable law by agreement. One of the special rules, Article 7, deals with environmental damage and reads as follows:

"The law applicable to a non-contractual obligation arising out of environmental
damage or damage sustained by persons or property as a result of such damage shall be
the law determined pursuant to Article 4(1), unless the person seeking compensation for

\footnotetext{
${ }^{61}$ Strikwerda, L., supra note 35, No. 184.

${ }^{62}$ Regulation (EC) No 864/2007 of the European Parliament and of the Council of 11 July 2007 on the law applicable to non-contractual obligations (Rome II), OJ 2007 L199/40.

${ }^{63}$ See generally Craig, P. \& De Burca, G., EU Law. Text, Cases and Materials, $4^{\text {th }}$ ed., Oxford, OUP 2008, p. 83. A Regulation is a type of Community law most akin to domestic primary or secondary legislation: a Regulation is of "general application [and] binding in its entirety and directly applicable in all Member States" (Art. 249 EC Treaty).

${ }^{64}$ See Convention on the law applicable to contractual obligations, Rome, 19 June 1980; latest consolidated version in OJ 2005 C 334/1. A Proposal to convert the Convention into a Regulation is currently before the Community legislature, see Proposal for a Regulation of the European Parliament and the Council on the law applicable to contractual obligations (Rome I), $\operatorname{COM(2005)~}$ 650, Brussels, 15 December 2005.
} 
damage chooses to base his or her claim on the law of the country in which the event giving rise to the damage occurred."

The provision allows the plaintiff to unilaterally select the applicable law albeit that the choice is limited to either the place of impact of the emissions - the place of damage, which is the general rule of the Regulation under Article 4(1) or Erfolgsort - or the place where the tortfeasor had acted, the Handlungsort. Of course such a choice only has meaning where these places are in different Member States but that will be the case in the classic scenarios of transboundary air or water pollution as well as cross-border transport of wastes. The provision empowers plaintiffs who may opt for the law of the place where the emissions came from where that law would offer them benefits which the law of the place of harm does not contain. Normally the latter would coincide with the jurisdiction of the plaintiff's domicile so that this provision contributes to enabling plaintiffs to choose the law with the highest level of protection. There is some controversy about the desirability of this unilateral choice as its effect is that plaintiffs suffering harm from abroad can get better protection than if they were harmed in the same way by a defendant based in their own country.

However, according to the European Commission, the victim's option to select the law of the place where the tortfeasor had acted (or to select the law of the place of impact/damage by relying on the general rule) contributes to raising the general level of environmental protection. The place of damage rule is "conducive to a policy of prevention obliging operators established in countries with a lower level of protection to abide by the higher levels of protection in neighbouring countries, which removes the incentive for an operator to opt for low-protection countries". ${ }^{65}$ But an exclusive application of the place of damage rule is regarded as an insufficient contribution to the overall objectives of environmental policy; operators established in border regions could then benefit from the lower levels of protection in a victim's home State. In the Commission's view, it is justified to offer the victim a choice of selecting the most favourable law as that reflects, at the level of choice of law, the policy to raise the general level of environmental protection in situations where the author of environmental damage, unlike most other torts, usually benefits economically from the harmful activity. ${ }^{66}$ Furthermore, application of the country of conduct's higher standards in this type of situation is justifiable in terms of party expectations, fairness and State interests. It would be untenable for operators to argue that they should not be subjected to the standards of their own country; once a violation has been established they should bear the consequences of

\footnotetext{
${ }^{65} \mathrm{COM}(2003) 427$ Explanatory Memorandum, p. 19.

${ }^{66}$ For a recent endorsement of Art. 7, see Kreuzer, K., "Die Vergemeinschaftung des Kollisionsrechts für ausservertragliche Schuldverhältnisse (Rom II)“, in Reichelt, G. and Rechberger, W.H. (eds.), Europäisches Kollisionsrecht (anwendbares Recht; gerichtliche Zuständigkeit; Vollstreckung von Entscheidungen im Binnenmarkt), Vienna, Manz-Verlag, 2004, 13 at 40-41.
} 
that without being able to invoke application of lower standards of another State. ${ }^{67}$ The State of the country of conduct has an interest in ensuring compliance with its law whereas the State of the country of impact has an interest in protecting its environment but not in displacing a rule of conduct of another State applicable to operators acting on the latter's territory by the former State's lower standards. To allow for the displacement of the higher standard undermines the effectiveness of the higher standard.

\section{Actors}

In this respect, the question arises who can bring a liability suit, but also who can be sued.

\subsection{Individual Victims as Plaintiff}

For obvious reasons, this is in cases of (transboundary) environmental pollution always a hot topic. Briefly addressing the issue who can bring a law suit, most legal systems will have no difficulty allowing the right to the individual victim who suffered personal and direct harm as a result of the transboundary pollution to bring a law suit. However, in many legal systems it is a requirement that the plaintiff must have suffered a personal harm in order to bring suit. For the market gardeners in the Bier case, this was no problem since they could argue that they were completely dependant on drainage water for the spraying of the crops cultivated by them. As a result of the emissions of salt waste into the river Rhine, the total salt burden increased and the gardeners suffered a diminution of the cultivated crops. ${ }^{68}$ They could hence be considered as victims who had a clear and direct interest at stake and in those cases, there is usually no discussion on the standing of the plaintiffs.

\subsection{NGO's as Plaintiff}

However, it is well-known that in many cases of (transboundary) environmental pollution, the damage may be so widespread that no individual victim has a sufficient incentive to bring a liability suit. Often, it is the public at large or a large group that suffers harm as a result of the transboundary pollution. In those cases, the question arises whether either environmental

\footnotetext{
${ }^{67}$ Symeonides, S.C., “Tort Conflicts and Rome II: a View from Across”, in Mansel, H.P. et al. (eds.), Festschrift für Erik Jayme, Munchen, Sellier/European Law Publishers, 2004, 935, para. 8.3, calling this a classic "false conflict."

${ }^{68}$ Betlem, G. (1993), supra note 6, 394-395.
} 
organisations or public authorities can have standing in court. ${ }^{69}$ Leaving aside the latter issue for a moment, one can notice that in the already mentioned Sopar case, the plaintiff was a Dutch non-governmental environmental organisation, Reinwater. Case law of the Hoge Raad in the Netherlands recognised, since its judgment of 1986, a right of standing of environmental organisations. ${ }^{70}$ Strict requirements apply. For the NGO to have standing under Dutch law, it was still necessary that there would be a possible impairment of the interests the NGO purports to promote. In the Sopar case, defendant Sopar contended before the court of appeals of The Hague that Reinwater had no standing because the interests it alleged was protecting were not included among the protected interests in the provision of the civil code concerning tort law. The court of appeals of The Hague, however, rejected that defence referring to the mentioned case law of the Hoge Raad and therefore held that Reinwater had standing to ask for an injunction against Sopar.

In 1992, in the Kuunders case, ${ }^{71}$ the Hoge Raad confirmed and specified its 1986 judgment. It now referred to ecological interests of individual citizens which are not suitable for protection by individual actions. A collective action by a public interest organization is therefore required, and justified, to guarantee efficient protection of these interests, according to the court. These and other rulings have been codified and extended in the Collective Actions Act 1994, albeit under certain restrictions. The Act has inserted Article 3:305a into the Civil Code, which reads as follows:

“1. An association or foundation with full legal capacity is entitled to entertain an action for the purposes of protecting interests of other persons that are similar in kind, inasmuch as it promotes these interests according to its articles of association.

2. A legal person within the meaning of Section 1 shall not have standing if and when it has insufficiently attempted, in the circumstances of the case, to reach the result sought by the action by way of consultation with the defendant. (...)

3. (...) An action as referred to in Section 1 cannot relate to damages in money.

4. An act cannot form the basis of an action within the meaning of Section 1 to the extent that the person affected by it objects to the action.

5. A judgment shall not be binding with respect to a person whose interests are being

\footnotetext{
${ }^{69}$ For a detailed discussion of these issues, see Betlem, G. (1993), supra note 6, 305-348 and Chapters 8 and 9 of Wilde, M., Civil liability for environmental damage a comparative analysis of law and policy in Europe and the United States, The Hague, Kluwer, 2002.

${ }^{70}$ Hoge Raad 27 June 1986, NJ 1987, 743.

71. HR 18 December 1992, NJ 1994, 139 note by Scheltema and Brunner; M en R 1993, 234 note by Kottenhagen-Edzes.
} 
protected by the action and who objects to the legal effect of the judgment as far as he/she is concerned, unless the nature of the judgment carries with it the impossibility to exclude its effects vis-à-vis this person alone."

It follows from this provision that standing to sue for an injunction is no longer an issue under Dutch tort law. Provided that the requirements of this Article are satisfied, a group action is admissible. However, there remains some uncertainty about the standing of an NGO who is not domiciled in the Netherlands.

Two issues need to be addressed: a preliminary and a substantive one. The substantive question is whether a non-Dutch NGO has standing to sue a multinational (based in the Netherlands or otherwise) before a Dutch court.

The preliminary question underlying this issue is: according to which law will this issue of admissibility (transnational locus standi) be decided by the Dutch court? In turn, this raises the qualification question of whether the admissibility issue is procedural, which means the lex fori is applicable, or a question dealt with by the law applicable to the substantive tort law issues - the lex causae. In our view, the question must be regarded as a substantive law issue for Article 3:304 Civil Code reads: `A right of action cannot be severed from the right it serves to protect.' Given the close relationship between the right and the action, the admissibility question will then be governed by the Dutch conflict of laws rule on torts. Assuming that this rule will point to Dutch substantive law as the lex causae, that legal system can than be expected to determine the locus standi of the foreign NGO. ${ }^{72}$ From 2009, the same will apply under Article 15 of the Rome II Regulation. ${ }^{73}$

The second issue is an interpretation in an international dispute of the provision in the Civil Code dealing with locus standi of public interest groups (Article 3:305a) and already cited above. The relevant question, in the transnational context, is whether the description of the purpose of an NGO will match the interest that has been harmed; both in a geographical and in a functional sense. When answered affirmatively, a non-Dutch NGO will have locus standi before a Dutch civil court, in our view. An analogy can be drawn with a domestic case involving the genetically modified bull 'Herman.' The genes of the bull were so modified that

\footnotetext{
${ }^{72}$ Cf. Article 7 of the Conflicts of Law in Tort Act (supra note 57), which indicates that the lex causae will, inter alia, determine who shall be entitled to compensation. By way of analogy this law should then also decide who should be able to apply for an injunction, either as a public interest litigant or as an immediate victim.

${ }^{73}$ See “(f) person entitled to compensation for damage sustained personally”.
} 
the milk from cows it fathered would contain a medicinal component. A legal action was brought by several organizations, including animal rights groups and environmental protection groups. The general environmental protection organization's purpose was held by the Dutch court not to be specific enough in this suit dealing with animals alone; only the claim by an animal rights group was admitted. ${ }^{74}$ If one extrapolates this decision to the transnational context, it follows that an NGO involved in the protection of the environment in e.g. Nigeria, would have locus standi in a suit involving damage to the environment in that country allegedly caused by a defendant based in The Netherlands (or who acted there), provided it can be regarded as an equivalent to `an association or foundation with full legal capacity' within the meaning of Article 3:305a CC. ${ }^{75}$

\subsection{Environmental Liability Directive and public authorities as plaintiff}

Also the recent European environmental liability directive (ELD) ${ }^{76}$ explicitly discusses the rights of environmental groups to ask for prevention or restoration of environmental harm under the scope of the directive. However, no rights to take any action themselves against operators are conferred on them by the Directive. They only are entitled to request competent public authorities to take action against operators. Such a request must be accompanied with evidence about the alleged (imminent) environmental damage. Judicial review of the authority's action or failure to act must be made available. ${ }^{77}$

Finally on the ELD, it may be noted that the only possible parties entitled to take any legal action against polluters are competent public authorities. As said, NGOs have no standing to sue operators directly. The regime has been largely configured as a domestic administrative law regime, imposing obligations to take preventive or remedial action on operators. The latter must bear the costs of such measures, either because they took them

\footnotetext{
${ }^{74}$ Cited by Robesin, M.A., "Procedeerlust Opwekkend en Remmend Privaatrecht”, in Van Acht, R.J.J. and Sicking, G.C. (eds.), Privaatrecht en milieu, Zwolle, Tjeenk Willink, 1994, 49 at 59.

${ }^{75}$ Vlas, P., "Het Verdrag inzake aansprakelijkheid voor milieugevaarlijke activiteiten en het internationaal privaatrecht”, Aansprakelijkheid \& Verzekering, 1993, 28 argues that such an organization must be recognized.

${ }^{76}$ Directive 2004/35/EC of the European Parliament and of the Council of 21 April 2004 on environmental liability with regard to the prevention and remedying of environmental damage, $O J$ L143, 30/04/2004, p. 56; for more details on its background and implementation please visit: $<$ www.environmentalliability.eu>.

${ }^{77}$ Arts. 12 and 13 of the Directive. See for a critical appraisal Krämer, L., "Directive 2004/35 on environmental liability and environmental principles," Special issue of TMA on the ELD, 4 TMA, 2005, 131-134.
} 
themselves or because they were taken by the authorities who are, under the Directive, obliged to recover those costs from the operator (subject to certain exceptions). Nevertheless, the ELD contemplates the eventuality of a cost recovery action against an operator based outside the Member State within which damage has occurred in Article 15(3), which reads as follows:

"Where a Member State identifies damage within its borders which has not been caused within them [...] it may seek, in accordance with this Directive, to recover the costs it has incurred in relation to the adoption of preventive or remedial measures."

In fact, even outside this specific rule on cross-border cost recovery, the question of the territorial scope of the core ELD obligations (Articles 5 and 6) arises. ${ }^{78}$ Art. 15(3) does little more than reState what is already possible: a Member State is not barred from bringing any recovery actions so it "may” of course do so. But is it not also allowed and required to take action against foreign-based operators under the Directive? This can be argued with respect to Article 5(3)b ELD stating that "the competent authority may at any time require the operator to take the necessary preventive measures". ${ }^{79}$ But how is this cost recovery or order to take measures against a non-domiciliary supposed to take place under public law? Administrative law is strictly territorial so any direct action against a foreigner must be based on private law, one would assume. ${ }^{80}$ In fact, the ELD mentions the Brussels I Regulation on civil judgments in the Preamble (and also refers to questions of choice of law):

“(10) [...] This Directive, which does not provide for additional rules of conflict of laws when it specifies the powers of the competent authorities, is without prejudice to the rules on international jurisdiction of courts as provided, inter alia, in Council Regulation (EC) No 44/2001 of 22 December 2000 on jurisdiction and the recognition and enforcement of judgments in civil and commercial matters".

If civil actions by public authorities were not envisaged under the indeed largely public law regime of the ELD, why is the Brussels I Regulation mentioned at all? A tort action would be a possibility either before the court of the domicile of the defendant or before the court of the

\footnotetext{
${ }^{78}$ Presentation Chris Clarke at ERA Conference on the Environmental Liability Directive, Brussels, 12-13 May 2005.

${ }^{79}$ And see its counterpart on remedial action: Art. 6(2)c; under Arts. 5(4) and 6(3) ELD the Member States must require operators to take these measures.

${ }^{80}$ Hence the existence of a Directive on cross-border enforcement in the field of consumer law, see Directive 98/27/EC of the European Parliament and of the Council of 19 May 1998 on injunctions for the protection of consumers' interests, OJ L166/51.
} 
place where the environmental damage occurred. In fact, it is conceivable that EC law not just does not oppose such a use of national tort law but actually requires it under Article 10 EC Treaty in conjunction with the duty to require operators to take measures under the ELD (Arts. 5(4) and 6(3)). If a Member State does not make a civil claim available, it can be argued that it has not correctly transposed the Directive into its own legal system and will thus be potentially liable to infringement proceedings under Article 226 EC Treaty. There is support for this view in the context of cases about protecting the financial interests of the Community. Article 10 EC Treaty (Community good faith; loyal cooperation) not just empowered but also required Member States, in the absence of a public law cause of action, to recover sums paid contrary to EC agricultural law on milk levies by way of civil action (including a free standing damages claim). ${ }^{81}$

Analogously, it can be argued that both the protection of the EC environment as well as the polluter pays principle in conjunction with the principle of effectiveness require that a civil action must be available either where there is a gap in the public law system or a public law route is impossible or excessively difficult in practice under the so-called Rewe provisos (principle of equivalence and principle of effectiveness). ${ }^{82}$ The latter is the case in crossborder situations.

\subsection{Public Authorities as Defendants: Immunity?}

We just mentioned public authorities as plaintiffs. But if a State is being sued before a civil court of another State, a further complexity arises: normally, that State will be able to rely on State immunity as a defence. This follows from a basic principle of international law, the equality of sovereignty of States. ${ }^{83}$ Under Dutch law, the jurisdictional immunity is expressed in Article 13a of the General Provisions Act 1829 and further elaborated in the 1972 European Convention on State Immunity. ${ }^{84}$ Immunity is not absolute nor does the court take it into account of its own motion: the foreign State can waive immunity; appearance before a court without raising the defence constitutes such a waiver. In addition, immunity only covers acts of State, so-called acta iure imperii and not acta iure gestiones (acts of a commercial

\footnotetext{
${ }^{81}$ Case C-230/01 Penycoed [2004] ECR I-937, paras. 36-38; [2004] 3 CMLR 32.

${ }^{82}$ Case 33/76 Rewe [1976] ECR 1989 and Case 45/76 Comet [1976] ECR 2043. See generally, Craig \& De Burca, supra note 63, at 305 et seq.

${ }^{83}$ See generally, Brownlie, I., Principles of Public International Law, $6^{\text {th }}$ ed., Oxford, OUP, 2003, 321 in particular; Chapters 14-16 passim.

${ }^{84}$ Strikwerda, L. supra note 35, No. 226; Brownlie, I., supra note 83, 332. The Council of Europe Convention was signed in Basel, 16 May 1972, Trb. 1973, 43; 11 I.L.M. 470 (1972); ETS 074; in force for the Netherlands since 1985, see <http://conventions.coe.int/>.
} 
nature). ${ }^{85}$ The 1972 Council of Europe Convention establishes common rules about the exceptions to immunity, beginning with submission to the jurisdiction (Art. 1), whilst confirming the basic principle of States' entitlement to immunity of jurisdiction. ${ }^{86}$ The most important rule of the European Convention in the present context is Article 11, which reads as follows:

\begin{abstract}
"A Contracting State cannot claim immunity from the jurisdiction of a court of another Contracting State in proceedings which relate to redress for injury to the person or damage to tangible property, if the facts which occasioned the injury or damage occurred in the territory of the State of the forum, and if the author of the injury or damage was present in that territory at the time when those facts occurred."
\end{abstract}

It follows that this provision does not lift immunity in the "normal” transboundary pollution scenario where a polluter acts in one State causing damage in another. For such a tortfeasor is not present in the State where the damage occurs. The provision is limited to situations such as traffic accidents in State A caused by a vehicle of State B. ${ }^{87}$ In addition, pure economic loss is not a recognised head of damage so that losses suffered by e.g. the market gardeners in the French potassium mines litigation would be excluded from this rule.

Whether State immunity would be an available defence in a scenario of cross-border pollution caused by States therefore depends entirely on the characterisation of their acts as being either acta iure imperii or acta iure gestionis. ${ }^{88}$ Although the test may be somewhat difficult to apply where State enterprises are involved, it would seem clear that where a State is alleged to have acted unlawfully because of a lack of supervision of operators or a breach of EC law in terms of defective transposition of a directive or the like it will be deemed to have exercised public authority powers. Accordingly, a foreign State would be able to invoke the defence of State immunity if it were sued before a civil court of another State.

What is the law when not a State as such but a regional authority or a constituent part of a State is being sued? Although the European Convention does not equate States with other public bodies and spells out that the latter may be sued in the same way as private parties,

\footnotetext{
${ }^{85}$ Strikwerda, L., supra note 35, citing HR 25 November 1994, NJ 1995, 660 Morocco v. De Trappenberg.

${ }^{86}$ See Arts. 15 and 24

${ }^{87}$ See the Explanatory Report to the Convention, para. about Art. 11, available from $<$ http://conventions.coe.int/>.

${ }^{88}$ See Dutch Supreme Court: HR 28 May 1993, Russian Federation v. Pied Rich, 41 Netherlands International Law Review 116 case note by De Waard (1994).
} 
pursuant to Article 27(2), regional or local authorities may likewise invoke the defence for their acta iure imperii. ${ }^{89}$

\section{Wrongfulness}

\subsection{Strict Liability or Negligence?}

A question that the court will ultimately have to answer within the context of such a transboundary liability suit is on the basis of which norms and how to judge whether the pollution caused by the defendant is to be considered wrongful in the sense that liability of the defendant will ensue. ${ }^{90}$ Until recently, there was no strict liability for transboundary environmental pollution in the sense that the polluter would be liable for any damage resulting from his activity, irrespective of his behaviour. Since almost any industrial activity creates risk of emissions, a broadly interpreted strict liability rule may potentially lead to such a far reaching liability that it may create a liability risk for any industrial activity. Especially in the transboundary context this may be problematic. In most transboundary pollution cases, one could therefore see the application of (a variation of) the negligence/nuisance rule. Depending upon the specific formulation, it would be examined whether the behaviour of the defendant was such that the pollution passed a certain threshold and therefore gave raise to liability. Also as far as State liability under international law is concerned, legal doctrine indicates that a finding of liability will depend upon a balancing of various factors. ${ }^{91}$ This became for example clear in the Trail Smelter case where it was held that "under the principles of international law no State has the right to use or permit the use of territory in such a manner as to cause injury by fumes in or to the territory of an other or the properties or persons therein, when the case is of serious consequence and the injury is established by clear and convincing evidence”. The balancing in this well-known passage already becomes clear in the fact that there is apparently liability only when "the case is of serious consequence" which implies that there is a certain level of pollution that must be accepted by the victim; only when a certain

\footnotetext{
${ }^{89}$ Meanwhile, a UN Convention was adopted in 2004. It is not yet in force. See United Nations Convention on Jurisdictional Immunities of States and Their Property, UNGA Resolution 59/38, available from unTreaty.un.org and the articles by Denza et al. in 55(2) ICLQ 395 et seq. (2006). Article 12 UN Convention is virtually identical to the cited tort provision of Art. 11 European Convention.

${ }^{90}$ For a discussion of this unlawfulness issue, see also Betlem, G. (1993), supra note 6, 349-442.

${ }^{91}$ For a discussion of the evaluation of State responsibility under international law see Sands, Ph., supra note 17, 134 ff.; Horbach, N.L.J.T., Liability versus responsibility under international law. Defending strict State responsibility for transboundary damage, diss. Leiden, 27 June 1996 and Lefebre, R., Transboundary environmental interference and the origin of State liability, The Hague, Kluwer Law International, 1996.
} 
threshold is passed may liability be accepted.

However, since 1995, the Dutch Civil Code includes a number of environmentally relevant strict liabilities. The main one is laid down in Article 6:175 CC. Its key elements may be translated as follows:

"1. He who, in the exercise of a profession or trade, uses or possesses a substance known to have such qualities so as to constitute a serious risk to persons and property, shall be liable when this risk materialises. Those using or possessing the substance shall include legal persons, in the exercise of their purpose. A serious risk shall be deemed to exist in any event where the substance is explosive, inflammable ... toxic according to Article 34(3) of the Environmentally Dangerous Substances Act [transposing the relevant EC Directive on the classification, packaging and labelling of dangerous substances]. ${ }^{92} \ldots$

4. Where the damage is a result of pollution by the substance of the air, water or soil, the liability under S. 1 shall lie with him who at the commencement of the polluting incident was designated as liable person under that provision. Where contamination is a result of exposure to the substance deposited into the water or the soil in a packaged condition, the incident shall be deemed to have commenced at the time of deposition....

6. A substance shall be deemed to satisfy the characteristics of Section 1 if and when it is so designated by Statutory Instrument. ...”

It follows that this provision lays down a no-fault liability for dangerous substances. The professional user of a dangerous substance is liable for damage caused by this substance; in the event of pollution, liability is connected to the person who was in possession of the substance at the time of the event leading to the damage. How is "dangerous substance" defined? This regime adopts an open system by referring to known properties but with an indicative list. Substances are deemed to be dangerous if placed on a list under a Statutory Instrument.

It may be noted that the regime had been vigorously opposed by Dutch industry for many years. Litigation with a crippling impact on companies was predicted. What has happened so far? Certainly not a deluge of cases. As far as we are aware from any published sources and from interviews with lawyers in the field, there is only one case so far. ${ }^{93}$ What are

\footnotetext{
${ }^{92}$ Directive 67/548/EEC, OJ 1967 L196/1, as amended and updated many times.

${ }^{93}$ Rechtbank Rotterdam 11 March 1999, TMA 2000, 119 (Van Brink Shipyard), with summary in
} 
we supposed to think about that? That is hard to say. Are the rules simply irrelevant or is there a preventive effect? An informed answer would need empirical research. In any event, one conclusion can be drawn. The so-called floodgates have not been opened: companies are not inundated by claims nor is there any indication that the existence of this regime has caused any problems to the Dutch industry.

\subsection{Violating a Regulatory Norm or a Duty of Care}

A finding of liability in a negligence regime supposes that the plaintiff proves that the defendant violated a standard of due care. In most legal systems, a distinction is made between two situations: on the one hand the situation where a specific regulatory regime exists (for example emission standards in a permit) which has been violated and on the other hand the situation where no such regulatory regime is at hand. In most legal systems, the first situation is the relatively easy one: many legal systems hold that as soon as a defendant violates a specific regulatory standard prescribing or prohibiting a certain behaviour, wrongfulness is automatically given. It is sometimes referred to as a per se rule of liability.

This type of liability rule was in fact applied in the Sopar case discussed before. The court of appeals of the Hague established that the defendant Sopar violated the norms laid down in the Belgian licence: Reinwater argued that Sopar discharged more than 100 micrograms of PAH per litre whereas the permissible quantities as set forth in the discharge permit were 30 micrograms per litre. Considering that Sopar grossly disregarded the conditions of its Belgian permit, the court of appeals of The Hague had no difficulty in allowing Reinwater's claim for compliance with the permit.

\subsection{Breach of Foreign Law}

The Sopar rulings are entirely consistent with the landmark Interlas judgment by the Hoge Raad. ${ }^{94}$ This case established two important rules. First, the Dutch Supreme Court held that breach of a statutory duty within the meaning of Dutch tort law (i.e. Article 6:162 Civil Code)

English; cited by Bauw, E. and Brans, E.H.P., Milieuprivaatrecht, $3^{\text {rd }}$ ed., Deventer, Kluwer, 2003, 159. Although the strict liability was accepted, the court ruled that there was no causal connection between the event giving rise to the liability and the losses in issue.

${ }^{94}$ HR 24 November 1989, NJ 1992, 404 (Focus Veilig/Lincoln Electric Company). 
covers any breach of an Act of Parliament, or a norm laid down in secondary legislation (either of a public or of a private law nature), whether of Dutch or foreign origin. In other words, where the defendant has acted contrary to an obligation of the domestic law of another country than the Netherlands, this is still a breach of a statutory duty. That concept is therefore not limited to breach of Dutch statutes. It follows that such foreign obligations can be enforced by Dutch courts, provided, of course, they have jurisdiction over the defendant in the first place. The issue of breach of foreign statutory duty must not be confused with the question of the choice of law in tort. It is only after it had first been established that Dutch tort law governs the dispute that this rule - as a rule of Dutch law - applies. The second rule of Interlas will be examined below (Section 7).

More complicated are of course the cases where there is no breach of a formal duty (Dutch or foreign) and therefore the court must examine in general whether the behaviour of the defendant was reasonable. Usually legal systems will apply some kind of a Roman law based bonus pater familias standard to compare the behaviour of the defendant with the behaviour of a normally diligent person in the same circumstances in order to decide whether the defendant should be held liable or not. ${ }^{95}$

\title{
6.4 Cases
}

The Bier case against the Alsacian Potassium Mines nicely shows the type of elements that have to be taken into account when judging the unlawfulness of the defendant's discharges. The Hoge Raad holds:

\begin{abstract}
"The criterion should be that whether a party who discharges substances into a river fails to observe its duty of care towards those using the river-water downstream depends on the nature, seriousness and duration of the damage caused to the latter and on the other circumstances of the case, among the factors to be considered here are, on the one hand, the nature and importance of the interests served by the discharges and, on the other hand, the interests served by the use of the water downstream and the extent to which this use is liable to be affected by the substances discharged. It should be borne in mind that in weighing up the respective interests, special importance must be attributed
\end{abstract}

\footnotetext{
${ }^{95}$ See for the different approaches in this respect Widmer, P. (ed.), Unification of Tort Law: Fault, The Hague, Kluwer Law International, 2005.
} 
to the interests of the user downstream and that such a user may in principle expect the river not to be polluted excessively by large discharges."

As far as the duty of care of the defendant is concerned, the Hoge Raad repeats the considerations held by the court of appeals:

"In order to answer the question whether MDPA acted in breach of this duty of care, it is necessary to weigh its interests against those of the market gardeners. It has to be borne in mind in this connection that the mutual interests are of a similar kind in that of the interests of both parties are of a financial and commercial nature”.

The court of appeals and subsequently the Hoge Raad therefore held that the MDPA violated its duty of care towards the market gardeners and holds the defendant liable. Of course, this balancing test based on the reasonableness of the discharges is more flexible and less clear cut as in case where a clear regulatory standard has been violated. The formula provided by the case law of the Hoge Raad is based on a balancing of all the relevant interests and circumstances of the case. Apparently, the Hoge Raad was of the opinion that the interests served by the users of the water downstream had to be given a higher importance than the nature and importance of the interests served by the discharges.

There is a third Dutch case which is worth mentioning in this respect because of the way in which the balancing of interests took place. It concerns a ruling of the president of the court of Maastricht of 3 February $1993^{96}$ about, again, a claim by the NGO Reinwater. This time, transboundary pollution of the river Meuse was at stake by inter alia Cockerill NV, a large factory situated in Belgium which allegedly emitted large quantities of, again, PAHs. ${ }^{97}$ In judging whether there was unlawfulness of the emissions of PAHs, the president of the district court of Maastricht holds that there is only unlawfulness if "the amounts of emitted PAHs would exceed every reasonable limit”. The president holds that Cockerill would discharge a yearly amount of PAHs of 30 kilograms. This would be approximately equal to the same amounts which would be discharged today by a similar corporation in the Netherlands. Hence, in this particular case, the judge in the victim State compares discharges in the polluter State

\footnotetext{
${ }^{96}$ Tijdschrift voor Milieuaansprakelijkheid (Environmental Liability Review), 1993, 137.

${ }^{97}$ See generally on transboundary pollution cases concerning the river Meuse Van Dunné, J.M. (ed.), Non-Point Source River Pollution: the Case of the River Meuse. Technical, Legal, Economic and Political Aspects, London, Kluwer Law International, 1996.
} 
with discharges of a comparable polluter in the victim State to judge whether the polluter has acted as bonus pater familias. Since the judge held that the foreign polluter would basically discharge the same quantity as a similar polluter in the victim State, the judge holds that there is no unlawfulness. ${ }^{98}$ However, Reinwater still obtains a modest success since the defendant Cockerill is required to produce information and obtain samples and measure the quality of its waste water twice a week and to provide the results of the analysis to Reinwater and this under a penalty payment of 10.000 Dutch guilders ${ }^{99}$ for each day that Cockerill would be in default.

Another type of question could still arise, being whether compliance with an explicit regulatory standard would have a justificatory effect in a liability suit. We will address this issue in section 8 below.

\subsection{Environmental Liability Directive}

Finally we should, as far as the unlawfulness issue is concerned, mention that within Europe environmental liability of operators is now to a large extent covered by the already mentioned environmental liability directive which also has consequences for cases of transboundary environmental pollution falling under the scope of the directive. However, important elements of the regime have been deliberately left to the national laws of the Member States. Put differently, they have not been harmonised. This includes the permit or regulatory compliance defence and the State of the Art defence. ${ }^{100}$ Indeed, the Directive does not cover any liability between private parties inter se by excluding all so-called traditional damage from its scope (it only concerns environmental damage as defined by the Directive). ${ }^{101}$

\footnotetext{
${ }^{98}$ Nevertheless, it appeared that this finding of the judge was based on a mistake in calculation. De facto, there was a considerable difference between the amounts discharged by the two factories in the different States.

${ }^{99}$ Today, this would amount to approximately 5.000 euros.

${ }^{100}$ Art. 8(4) ELD.

${ }^{101}$ See Preamble, recital 14, which provides as follows: "This Directive does not apply to cases of personal injury, to damage to private property or to any economic loss and does not affect any right regarding these types of damages", and Art. 3(3), which reads: "Without prejudice to relevant national legislation, this Directive shall not give private parties a right of compensation as a consequence of environmental damage or of an imminent threat of such damage.”
} 


\section{Applicable remedies}

The type of remedy sought by a plaintiff will in these type of (transboundary) pollution cases often be closely related to the nature of the plaintiff. When the plaintiff is a traditional victim suffering personal injury or economic losses, the plaintiff can, depending upon the rules in his national legal system, obtain damages that should in principle aim at restoring the victim in the status quo ante. NGO's can ask for either an injunction aiming at preventing further harm by ordering the defendant to stop the polluting discharges or to restore harm done. In practice, there may be overlap between the reparation in kind and the injunction. ${ }^{102}$

The Hoge Raad decision concerning the Alsatian potassium mines made clear that there is a difference between a claim for compensation of costs or (economic losses) on the one hand and an injunction asking de facto that the polluting activity would be stopped on the other hand. The Dutch market gardeners asked in their case against the Alsatian mines to be paid the costs of additional measures which they had to take as a result of the wrongful discharges of salt waste by the MDPA into the river Rhine. The defendant inter alia held that holding against them in a liability case could lead to seriously affecting the socio-economic interests of the whole region. It may mean that MDPA would have to shut down with a loss of many jobs as a consequence. The Hoge Raad, however, was not impressed with that argument and clearly indicates that the plaintiffs in the case (Bier and other market gardeners) do not ask an injunction in which they ask either the shut down of the enterprise or of the wrongful discharges. The gardeners only claim recovery of additional costs they incurred themselves. The Hoge Raad therefore holds:

\footnotetext{
"The court of appeal rejected MDPA's argument that if it were forced to stop the salt discharges, it would have to close down the mines altogether and its interests would thus be gravely affected. The ground for rejection was that in advancing this argument MDPA overlooked the fact that an application had been made not for an injunction to hold the discharges but for compensation for the damage caused by them. It does not follow from this that the alleged unlawfulness should be judged differently according to whether an injunction or compensation is being sought or that the discharges are not in themselves unlawful but are tortuous only in conjunction with MDPA's failure to pay compensation for the damage.
}

As it therefore does not automatically follow from a court's finding in favour of plaintiff

\footnotetext{
${ }^{102}$ See Betlem, G. (1993), supra note 6, 491-493.
} 
seeking compensation that an application for an injunction would likewise have to be granted if it were lodged, it was possible for the court of appeal to disregard MDPA's interest in the continued operation of the mines".

The Hoge Raad therefore holds that in principle no different standard of unlawfulness applies, but that in case an injunction is sought, an additional test will be applied. In the latter case, social (more particularly employment) interests may be weighed to examine whether the injunction should be granted when the behaviour of the defendant has been qualified as unlawful. $^{103}$

The two other mentioned Dutch cases showed that the plaintiffs (NGO's) asked for an injunction and obtained their injunction. However, in both cases the scope of the injunction was relatively limited. The court of appeal of The Hague ordered in its decision of 19 November 1992 defendant Sopar to fully comply with all conditions of its permit with a penalty of 50.000 Dutch guilders ${ }^{104}$ for each day that it remained in non-compliance. As we mentioned above, the president of the court of Maastricht held in her decision of 3 February 1993 that Cockerill was required to produce information and make measurements available to Reinwater twice a week, again under the threat of a penalty payment. The penalty payment is added in each case to guarantee that the injunction which has been ordered by the court will also be complied with.

In principle non-governmental organisations do not have the right to claim damages for the damage to the environment itself. The NGO can, on the basis of its interest as defined in its purpose, have standing to ask for an injunction which may lead to prohibiting actions which may endanger the interests it serves. But because the NGO does not own the environment of which it purports to protect the interests, it cannot claim damages for the harm that would be caused. There is, however, one important exception to this rule in case an NGO would make costs to e.g. clean birds if that would be the stated interest of the particular foundation. There is a 1991 Dutch first instance judgment confirming this possibility but before discussing it, we would like to place the ruling in the wider statutory context, including international conventions, which is about claiming compensation for preventive measures.

\footnotetext{
${ }^{103}$ See on this difference Betlem, G. (1993), supra note 6, 495 and below section 6.1.

${ }^{104}$ Today, it would be approximately 25.000 euros.
} 


\subsection{Article 6:184 Dutch Civil Code: costs of preventive measures ${ }^{105}$}

This provision provides that "damage" includes the costs of reasonable measures to prevent or limit the damage taken by any person after a serious and imminent threat of occurrence of such damage has arisen; it is a lex specialis complement to the strict liability for dangerous substances cited above (Art. 6:175 CC). The crucial added value of this special regime compared to the general law of damages under the Civil Code is the explicit inclusion in Art. 6:184 CC of the phrase: "taken by any person.” There is not necessarily a difference in substance though because even under the general provisions on Dutch law of damages, such costs are recoverable as a matter of course. For Article 6:96 CC refers to reasonable costs of preventing or limiting the loss. Although this provision does not indicate who may be entitled to claim these costs, it is argued in doctrine that in addition to the victim who personally suffers loss, third parties may be likewise entitled. ${ }^{106}$ It follows, in this view, that claims for recovery of costs by governmental bodies and NGOs if and when they have taken such measures are included under both the general Dutch law of damages and the special provision on recoverable loss under the strict liability for dangerous substances (Art. 6:175, examined above). Also, as will be seen below, the reference to "any person" of Art. 6:184 CC is in line with similar provisions in international conventions and enables third parties to recover their costs.

However, there is a further rule under Art. 6:184 CC (damages in context strict liability for dangerous substances) that qualifies this basic starting point for the situation where these measures are taken by others than those who would actually suffer the loss. These third parties can only claim what the 'real victims’ would have been able to claim had they taken the measures themselves. The provision (section 2 of Art. 6:184) thus introduces a somewhat complex hypothetical element. The initial “actio popularis," i.e. a claim for costs for recovery of measures taken by whomsoever (third party), is linked to recoverable loss by a hypothetical first party victim: if the latter cannot recover certain losses the former cannot do so either. This restriction is particularly relevant in claims by a governmental body - e.g. a claim after a clean-up operation on a beach cannot include parts of the costs related to general environmental policy on prevention of pollution - as well as by NGOs. The costs of preventive measure cannot be recovered for loss which does not entail any other person's property damage or pure economic loss. Typically, damage to the unowned environment e.g. wild birds as res nullius - does not entail anybody's patrimonial loss. ${ }^{107}$ Claims by NGOs

\footnotetext{
${ }^{105}$ This section is based on Betlem, G., "Strict environmental liability and NGO damages and enforcement claims: a Dutch and international law perspective”, in Hamer, J. (ed.), Environmental Liability in the EU, Trier, ERA, 2002, 131.

${ }^{106}$ Messer, E.A., Risico-aansprakelijkheid voor milieuverontreiniging in het BW, Arnhem, Gouda Quint, 1994, 123.

${ }^{107}$ See generally (in Dutch) Carette, A., Herstel van en vergoeding voor aantasting aan niet-toegeëigende milieubestanddelen, Antwerpen-Groningen, Intersentia, 1997.
} 
are therefore limited under this system. If as a result of an oil spill or other contamination covered by this regime, seabirds are affected and costs are made to restore the damage to these birds, these cannot be claimed because they have no owner nor another economically interested potential real victims such as in the case of fishermen. ${ }^{108}$ Although in the absence of case law there is a lack of clarity about the exact limits of the scope of this provision, it does seem to exclude recovery of clean-up costs in a situation where nobody would be able to suffer any property damage or economic loss. ${ }^{109}$

The result of this linkage between the costs of preventive measures incurred by third parties and ‘classical' property or economic damage is a somewhat surprising distinction between species of wild animals. George Orwell, however, probably would not have been surprised: after all some animals are more equal than others ... This is all the more peculiar and ironic as NGOs have been able to claim the costs of remedying damage to seabirds not under this special regime but under the general tort law rules of the Dutch Civil Code. One could thus argue that an NGO taking preventive measures does not act as a third party at all but simply recovers costs as a first party victim; the restriction regarding third party claims of Art. 6:184(2) CC would not then be applicable. ${ }^{110}$ However, in our view, NGOs do not seem to be able to get round the restrictions of this provision as their claim entirely consists of the costs of preventive measures; unlike a 'real victim’ who would incur such costs in order to prevent or limit other loss he would suffer. ${ }^{111}$ With respect to the NGO - even if one would regard it as a primary victim, they have no other loss than these costs. It would follow that they cannot rely on the strict liability for dangerous substances to claim these costs but would have to fall back on the general tort law rules of the Dutch Civil Code. As said, that is possible since a 1991 judgment.

\subsubsection{Borcea}

The Borcea case ${ }^{112}$ is particularly relevant from a comparative perspective, both in terms of the difference between the strict liability regime of Art. 6:184 CC and the general Dutch damages rules as well as in terms of comparing this case to environmental liability regimes under international conventions (below para. 6.1.2). The facts are as follows. A Rumanian

\footnotetext{
${ }^{108}$ Messer, E.A., supra note 106, 127; Frenk, N. and Messer, E.A., “Ongekende mogelijkheden voor milieuorganisaties!?”, Kwartaalbericht Nieuw BW, 1991, 14 at 16.

${ }^{109}$ See also Spier, J. et al., Verbintenissen uit de wet en Schadevergoeding, 4th ed., Deventer, Kluwer, 2006, No. 133; Bauw, E. and Brans, E.H.P., supra note93, 49-53.

${ }^{110}$ Bauw, E. and Frenk, N., "Nieuwe perspectieven voor milieu-organisaties", Nederlands Juristenblad, 1991, 1259.

${ }^{111}$ See Betlem, G., [Recovery of Costs by Environmental NGOs] "Kostenverhaal door milieuorganisaties”, in Van Buren-Dee, J.M. et al. (eds.), Privaatrecht en Gros. Liber Amicorum F.W. Grosheide, Antwerpen-Groningen, Intersentia, 1999, 133 at 141.

${ }^{112}$ District court Rotterdam 15 March 1991, (1992) 23 Netherlands Yearbook of International Law 513.
} 
bulk carrier leaked oil (which was used as fuel) close to the Dutch coast. Thousands of affected birds were found on the beaches of the provinces Zeeland and Zuid-Holland. The Dutch Association for the Protection of Birds, whose purpose according to its articles of association is the protection of wild birds by all lawful means, operates bird-asylums/birdshelters. They incurred costs by transporting the birds from the beaches to the asylums, by cleaning them etc.; in short, they incurred 'bird clean-up' costs. For the first time, the district court Rotterdam allowed a public interest group's action for damages for such costs. In an interlocutory judgment - the plaintiffs are ordered to substantiate proof of a sufficient causal connection between the damage and the allegedly tortious conduct of the vessel's captain - it held the following concerning the plaintiff's entitlement to an action for damages:

“... according to contemporary societal views, the conservation and protection of seabirds is a general interest worthy of protection in the Netherlands... it is also the plaintiff's own interest; ... when that interest is harmed, not only an injunction is admissible, but also a claim for compensation for damage which was incurred due to limiting the consequences of the infringement of that interest [emphasis added]."

It follows that bird protection organisations can claim damages for costs voluntarily incurred due to their bird protection activities; in the case in hand, the parties reached a settlement for a hundred thousand Dutch guilders. ${ }^{113}$ One of the decisive factors for the court was that the plaintiff pointed out that, to a certain extent, it carried out State tasks, since it was designated by the Ministry of Agriculture and Fisheries as coordinator for oil disasters. The Rotterdam court accepted that the general interest of environmental protection does not only have to be pursued by the State (or other public authorities): it is not necessarily a State monopoly. It drew the logical conclusion by allowing the NGO to proceed with a claim on a similar footing as the public authorities. ${ }^{114}$

Regarding precisely what costs the bird protection organization claimed, the following may be noted. On the one hand the costs of transporting the birds and cleaning them were claimed; on the other, part of the overhead costs of the bird asylums. Both types of costs are recoverable under well established case law of the Dutch Supreme Court. ${ }^{115}$ Especially interesting is that these costs in fact concerned the reparation (as far as possible) of ecological damage, i.e.

\footnotetext{
${ }^{113}$ See De Volkskrant of 13 February 1992, 7.

${ }^{114}$ Ironically, the State's claim for clean-up costs eventually failed on the ground of lack of causal connection between the loss incurred and the alleged unlawful failure to report the oil spill, see Borcea II: District Court Rotterdam 24 February 1995, Tijdschrift voor Milieu en Recht 1996, No. 43, Tijdschrift voor Milieu Aansprakelijkheid/Environmental Liability Law Review 1996, 6.

${ }^{115}$ See Asser-Hartkamp I (C. Asser's Handleiding tot de beoefening van het Nederlands burgerlijk recht, Verbintenissenrecht, Deel I, De verbintenis in het algemeen), No. 414 and the above mentioned costs of preventive measures.
} 
damage to birds which belong to nobody. In this respect, as said, given the cited restriction under Art. 6:184 CC, there is a wider protection under general tort law than under the specific liability for dangerous substances. The disadvantage for the NGO is, however, that it cannot benefit form the strict liability to claim these costs.

Insofar as they can be claimed, the costs were incurred while limiting the consequences of an oil spill. We shall see in the next section that the result of this Borcea case - viewed in terms of damage limitation measures - is in keeping with definitions of compensable loss under various international conventions; as such there is international consensus about allowing this claim.

\subsubsection{International Conventions}

On first sight, the damages claim for NGOs would not be allowed under the Council of Europe Lugano Convention. ${ }^{116}$ Article 18 deals with "Requests by Organisations" and entitles NGOs to bring the following actions:

- a prohibition of an unlawful dangerous activity which poses a grave threat of damage to the environment;

- an order the operator to take measures to prevent damage, before or after an incident;

- an order the operator to take measures of reinstatement.

These are three actions for an injunction; the provision does not include damages. However, the rules on locus standi are not the final answer: we must also look at the definition of compensable loss to get the complete picture on possible actions by NGOs and then we see a different picture. That is to say that - just as noted above under Dutch law - the Lugano Convention includes the possibility to claim the costs of preventive measure. It defines them in Article 2(9), which reads as follows:

"'Preventive measures' means any reasonable measures taken by any person, after an incident has occurred to prevent or minimise loss or damage as referred to in paragraph 7, sub-paragraphs a to c of this Article [emphasis add.]"

This definition is a widely adoption formulation of the concept of recoverable costs of preventive measures; ${ }^{117}$ it first appeared in the maritime law sector, from which it has been

\footnotetext{
${ }^{116}$ Convention on Civil Liability for Damage resulting from Activities Dangerous to the Environment, Lugano, 21 June 1993, European Treaty Series 150 (<http://conventions.coe.int>), 32 International Legal Materials (I.L.M.,1993); not in force; signed by Cyprus, Finland, Greece, Iceland, Italy, Liechtenstein, Luxembourg, the Netherlands and Portugal.

${ }^{117}$ See generally Larsson, M.-L., The Law of Environmental Damage. Liability and Reparation, The
} 
copied. ${ }^{118}$ The same definition has subsequently been adopted in numerous other conventions including the so-called HNS Convention, ${ }^{119}$ the 1997 Vienna Convention on Civil Liability for Nuclear Damage ${ }^{120}$ and the 1999 Basel Protocol on Liability for Damage resulting from the Transboundary Movement of Hazardous waste. ${ }^{121}$

Since these provisions grant the right to claim the costs of preventive measures taken by "whomsoever" or by "any person", public interest groups are entitled to a claim for reimbursement if they have incurred such costs. This view is supported by the "case law" of the International Oil Pollution Compensation Fund (IOPC Fund), where it decides on claims under the 1969 Oil Pollution Convention. ${ }^{122}$ With respect to "preventive measures" it has recognised that "clean-up measures by voluntary groups ... satisfy the requirements for consideration as preventive measures" and are thus recoverable in the context of the Fund. ${ }^{123}$ Comparable to the cited Dutch Borcea case, the Fund has ruled in the Braer case that the costs of caring for "injured wildlife" by environmental protection groups are recoverable provided, of course, they were reasonably incurred. ${ }^{124}$

In conclusion, the possibility of damages claims by NGOs under certain circumstances has been accepted by most States in the context of relevant international conventions, i.e. those dealing with civil liability of operators for activities causing damage to the environment such as nuclear incidents, oil spills and other hazardous substances. Provided NGOs are legally capable of carrying out remedial actions, they will be able to claim the costs thereof from those responsible for the damage. Certain restrictions applicable under the Dutch regime of

\footnotetext{
Hague and Stockholm, Kluwer Law International \& Norstedts Juridik, 1999, 172 et seq. and see Kottenhagen-Edzes, P., "De begrippen milieu-aantasting en milieuschade in enkele internationale verdragen, bezien vanuit privaatrechtelijk perspectief,” in Deketelaere, K. et al. (eds.), Grensoverschrijdende milieuproblemen: uitdagingen voor de nationale en internationale rechtsorde, Antwerpen-Groningen, Intersentia, 1998, 207.

${ }^{118}$ See Article I(7) of the 1969 International Convention on Civil Liability for Oil Pollution Damage, Brussels, 29 November 1969, Tractatenblad 1970, 196; 9 I.L.M. 45 (1970), as amended.

${ }^{119}$ International Convention on Liability and Compensation for Damage in connection with the Carriage of Hazardous and Noxious Substances by Sea, London, 3 May 1996, 35 I.L.M. 1406 (1996), $<$ http://fletcher.tufts.edu/multi/texts/IMO.txt>.

${ }^{120}$ Consolidated text of the Vienna Convention on Civil Liability for Nuclear Damage of 21 May 1963 as amended by the Protocol of 12 September 1997, 36 I.L.M. 1454 (1997), <http://www.iaea.org/GC/gc41/documents/gc41inf13a1.html>.

${ }^{121}$ Basel, 10 December 1999, http://www.basel.int for the text and signatures/ratifications; see generally French, D.A., "The 1999 Protocol on Liability and Compensation for Damage Resulting from the Transboundary Movements of Hazardous Wastes and their Disposal,” Environmental Liability, 2000, 3.

${ }^{122}$ Supra note 118.

${ }^{123}$ Gauci, G., Oil Pollution at Sea. Civil Liability and Compensation for Damage, Chichester etc., Wiley, 1997, 36 referring to FUND/EXC.34/9, 12 March 1993, § 3.28.

${ }^{124}$ Wu C., Pollution from the Carriage of Oil by Sea: Liability and Compensation, London etc., Kluwer, 1996, 291, referring to FUND/EXC.34/5/Add.1, 1 March 1993, p. 9.
} 
no-fault liability for dangerous substances are in fact out of step with these international developments. However, if and when the NGOs are able to rely on the general tort rules, Dutch law is in line with the international conventions.

\subsubsection{Other recoverable costs: detection costs}

Finally in this context, the question arises to what extent the Borcea case - damages for bird clean-up costs under general Dutch tort law - is a precedent for other claims of environmentalist organisations than the reimbursement of these bird clean-up costs. One could think of the costs of sampling and other research costs. Above we have already mentioned the Cockerill Sambre case (Section 6.3) and its injunction requiring the defendant to provide information. In addition, the Court of Appeal Den Bosch in 1998 upheld a ruling of a lower court in the case of Edelchemie (in English: Noble Chemistry). ${ }^{125}$ Essentially, it was held that the plaintiffs/NGOs are entitled to an advance of 20.000 Guilders ${ }^{126}$ for the costs they had incurred in commissioning technical experts for measuring the defendant/operator's emissions. The case involved nuisance in the form of unpleasant odours produced by a photochemical plant. One of the conditions of the licence it was operating under contained a standard prescribing a certain level of smell-units as an hourly average per cubic metre near neighbouring homes and offices during more than $2 \%$ of the time. The operator systematically did not comply with this norm which constitutes breach of a statutory duty under Dutch tort law.

Accordingly, the main action was for an injunction ordering the operator to fully comply with its licence. The court granted the order as well as the usual periodic penalty payment (the sanction for non-compliance with court orders under Dutch law), in this case: 25.000 Guilders per day of non-compliance with the court's order. In addition, the claim for compensation for detection costs - as said - was granted. The court refused to uphold the plaintiffs' third claim, which was to order the operator to commission an independent expert to measure immissions and to send the results to the plaintiffs. The judge stated that this would amount to a reversal of the burden of proof in that the defendant must prove it does not act unlawfully. This burden is with the plaintiffs to prove unlawful action. It may be noted in passing, that this aspect of the ruling illustrates that Dutch law would benefit from a future EU regime which presumably - like the Lugano Convention ${ }^{127}$ and German law ${ }^{128}$ - would

\footnotetext{
${ }^{125}$ District court Roermond 9 January 1998, unreported, cause list No. 24453/KGZA 97-288); confirmed on appeal by Court of Appeal Den Bosch 26 August 1998, Tijdschrift voor Milieu en Recht 1999, No. 22.

${ }^{126}$ Currently some 10.000 euros.

${ }^{127}$ See supra note 116.

${ }^{128}$ Messer, E.A., supra note106, at 175 referring to the Umwelthaftungsgestez (Environmental Liability Act), the Gentechnikgesetz (Genetic Technology Act) and the Bundesberggesetz (Federal Mining Act).
} 
contain a right to environmental information for plaintiffs to be exercised against operators.

The most notable point about mentioning this case here is that since it is up to the plaintiff to furnish proof, the costs to do so are recoverable not only where private persons or companies sue but also in actions brought by NGOs. In itself this is no surprise at all as it merely means that once the access hurdle has been taken, the NGO as any plaintiff can simply invoke the "normal" rules of tort law and civil procedure, including the law of damages. The latter includes Article 6:96 CC which defines the concept of material loss in broad terms ("S. 1. Patrimonial damage comprises both the loss sustained by the creditor and the profit of which he has been deprived.”) The provision also list some categories of recoverable costs:

"2. Furthermore, the following costs may be claimed as patrimonial damage: reasonable costs to prevent or mitigate damage which could be expected as a result of the event giving rise to liability; ${ }^{129}$

reasonable costs incurred in assessing damage and liability" (emphasis added) ...

This latter category is closely connected with a party's capacity as plaintiff in a civil action rather than with the more substantive notion of victim or person actually suffering loss himself. Therefore, such a claim by an NGO fairly and squarely fits in with the system of the law of damages, the law of tort and civil procedure. Accordingly, what has been termed "detection costs" are nothing but a specific application in an environmental context of the general notion of costs involved in assessing damage and liability. Like the recovery of costs of preventive measures, these costs are recoverable by NGOs without the need for any additional rules on locus standi or rules on access to remedies. Both types of damages claims are implicit in the concepts of the law of damages.

\subsection{Cross-border Injunctions}

Above we cited the Interlas judgment by the Hoge Raad and noted that two important rulings are included. ${ }^{130}$ The first one dealt with breach of foreign statutory norms and was discussed above in Section 6.2.1. The second one concerns the availability of injunctions which must be complied with outside the Dutch jurisdiction. Also in this respect the Sopar rulings are entirely consistent with Interlas, where the Hoge Raad ruled on the territorial scope of an

\footnotetext{
${ }^{129}$ Recovery of these costs is the necessary complement of the victim's duty to exercise reasonable diligence to limit the extent of the loss. This duty to mitigate loss has been recognised as a general principle of European tort law by the European Court of Justice, see in particular Joined cases C-46 and C-48/93 Brasserie du Pêcheur and Factortame [1996] ECR I-1029 and Joined Cases C-397/98 and C410/98 Metallgesellschaft and Others [2001] ECR I-1727 (judgment of 8 March 2001).

${ }^{130}$ Supra, note 94.
} 
injunction granted by a Dutch court. It held that court orders which command defendants to comply with their obligations can be granted also when such compliance must take place outside the Netherlands. To be exact, the Sopar judgment of the The Hague court of appeal fully matches the ratio decidendi of the Interlas judgment, for that provides as follows:

\begin{abstract}
4.2.4 (...) Unless the law, the nature of the obligation or a juridical act produce a different result, the person who is obliged to give, to do or not to do something vis-à-vis another, is ordered to do so by the court upon the demand of the person to whom the obligation is owed. In general there is no reason to accept that such an order cannot be given when the obligation - possibly an obligation under foreign law - is to be complied with outside the Netherlands. A more restrictive view as upheld in the cassation pleadings has no basis in law and would have, in a time of increasing international contacts, the undesirable effect on legal practice that, in international tort cases - such as infringement of intellectual property rights, unlawful competition involving several countries and transfrontier pollution - the Dutch victim might be compelled to apply to a court in all the countries involved. [Emphasis added.]
\end{abstract}

It is noteworthy that this ruling is of general application. The first sentence of this passage is nothing else than Article 3:296 Civil Code, providing the legal basis for injunctions sanctioning all kinds of legal obligations. Also, the Hoge Raad itself included an explicit reference to transfrontier pollution whereas the Interlas case itself solely relates to intellectual property. Accordingly, there is no doubt that this ruling is not limited to infringements of patents, trade marks and the like. From a private international point of view, the Interlas judgment should be classified as dealing primarily with the law of remedies, albeit that a number of aspect are closely connected with questions of international competence and recognition and enforcement of foreign judgments. ${ }^{131}$ The availability of transfrontier injunctions therefore is a matter for the law governing the dispute - the so-called lex causae. As said, in the cases under discussion here, Dutch tort law applied. But this does not mean that Belgian law was irrelevant. On the contrary, it follows from these two cases - Sopar and Interlas - that enforcement of Belgian public environmental law by Dutch public interest groups before the Dutch civil courts is a legal reality.

According to the Hoge Raad, an extraterritorial injunction should be available in the light of increasing international contacts. It thus practised a kind of `international interpretation' of the Civil Code: it construed the term 'obligation' within the meaning of Article 3:296 as encompassing obligations under Dutch as well as foreign law. ${ }^{132}$ This means

\footnotetext{
${ }^{131}$ See Polak, M.V., Civiele Sancties in het Internationale Geval voor de Nederlandse Rechter, Studiekring "Prof.mr. J. Offerhaus", Deventer, Kluwer, 1995, at No. 20.

${ }^{132}$ See also Polak, M.V., supra note 131, No. 21.
} 
that the provision's main rule, a right to a remedy to enforce obligations, has been internationalized. It would seem to follow that the provision's exception should also be so construed. The word "law," within the meaning of Article 3:296, which possibly bars this right to a remedy, should then also be read as including Dutch as well as foreign law. This view could be supported by the Hoge Raad's interpretation of the related Article 6:168 Civil Code in the cited MDPA case. This provision reads:

1. The judge may reject an action to obtain an order prohibiting unlawful conduct on the ground that such conduct should be tolerated for reasons of important societal interests. The victim retains his right to reparation of damage according to this title. (...)

3. The judge may as yet issue an order prohibiting the conduct where a condemnation to pay damages or to furnish security is not complied with. [Emphasis added.] ${ }^{133}$

In its cited decision in cassation the Dutch supreme court recognized that the term important societal interests' includes not only Dutch but also foreign, in casu French, interests. This follows from the fact that this provision is just as much applicable in international as in purely domestic cases. Accordingly, the Civil Code provides a system of checks and balances with respect to international remedies. Or, as suggested by Polak, the Interlas point of departure of worldwide extent of injunctions is balanced by a kind of doctrine of "sanctio non conveniens"'. ${ }^{134}$ Depending on the circumstances of the case, the courts may reject a plaintiff's entitlement to an extraterritorial injunction on a number of grounds such as important societal interests'.

However, it should be noted that in principle the environmental plaintiff will not encounter great difficulties in securing a remedy when the defendant has breached a statutory duty (leaving aside possible restrictions of the sanctio non conveniens-type).

\subsection{US Citizen Suits: the Pakootas Case C135 $^{135}$}

Above, we have already referred to the most famous case about transboundary air pollution in public international law, to wit Trail Smelter. ${ }^{136}$ The events leading up to the international Tribunal's rulings happened between 1925 and 1941. Subsequently and before, hazardous materials including heavy metals such as cadmium (forming slag) were also discharged into

\footnotetext{
${ }^{133}$ English translation by Haanappel, P.P.C. and Mackaay, E., New Netherlands Civil Code: Patrimonial Law, Deventer-Boston, Kluwer, 1990, 301.

${ }^{134}$ Polak, M.V., supra note131, No. 29.

${ }^{135}$ This section is based on Betlem, G., "Trail Smelter II: Transnational Application of CERCLA Pakootas v. Teck Cominco Metals Ltd., 452 F.3rd 1066 (9th Cir. 2006),” 19(3) Journal of Environmental Law, 2007, forthcoming.

${ }^{136}$ Supra note 17.
} 
the Columbia River. The slag travelled downstream from Canada into the US, where it accumulated over the years in the sediment of the river and Lake Roosevelt. Leachate of the heavy metals from the deposited slag caused harm to the environment and human health; there is ample evidence that the main source of the pollution is Teck Cominco's plant in Trail. ${ }^{137}$ Particularly affected are the Indian tribes who live in the Colville and Spokane Reservations who use these waters for fishing and recreation. ${ }^{138}$ To date no clean-up action has been undertaken. In this section, we examine a civil liability follow-up of Trail Smelter, which provides an important illustration of the use of so-called citizen suits in a transboundary scenario.

\subsubsection{Action by the US Environmental Protection Agency (EPA)}

CERCLA (Comprehensive Environmental Response, Compensation, and Liability Act), or Superfund, is the main federal US statute in the field of environmental liability. ${ }^{139}$ Among other things, it imposes strict, retrospective and joint and several liability on potentially responsible parties for releases of hazardous substances, including on those who arranged the disposal of the substances. It does not contain any regulatory standards such as emission norms; instead it focuses on remediation and clean-up of hazardous waste sites in the US. ${ }^{140}$ The EPA is the public authority empowered to implement and enforce the statute. On request of the Colville Tribes, EPA conducted preliminary assessments of a particular section of the Upper Columbia River; it concluded that it was a highly contaminated site eligible for inclusion on the National Priorities List. EPA opened informal negotiations with the American subsidiary of Teck Cominco so as to persuade it to conduct a Remedial Investigation and Feasibility Study of the site. ${ }^{141}$ As no settlement could be reached, the EPA then issued a unilateral administrative Order for a Remedial/Feasibility Study to Teck Cominco (Canada) under S. 9606 CERCLA. The addressee refused to comply and enlisted the support of the Canadian government arguing that CERCLA cannot be relied upon against a Canadian based company. The EPA has not enforced the order. However, members of the Colville tribes took up the case as a matter of private enforcement pursuant to CERCLA's citizen suit provision.

\footnotetext{
${ }^{137}$ Robinson-Dorn, M.J., “The Trail Smelter: Is What's Past Prologue? EPA Blazes a New Trail for CERCLA,” 14 N.Y.U. Env. L.J., 2006, 233-321 at 265-267.

${ }^{138}$ Pakootas 452 F. $3^{\text {rd }}$ at 1069.

13942 U.S.C. § 9601 et seq.

${ }^{140}$ Robinson-Dorn, M.J., supra note 137, 275.

${ }^{141}$ Ibid. at 268.
} 


\subsubsection{Judgment}

For the first time, US courts have applied CERCLA in a cross-border context. In July 2006 the US Court of Appeals affirmed the key findings of the first instance ruling by the District Court for the Eastern District of Washington. ${ }^{142}$ However, as further examined below, some aspects of the reasoning of the two courts differ; notably about the key issue of whether CERCLA had been applied extraterritorially or not. The judgments on appeal as well as in first instance do not deal with any legal proceedings by the EPA itself. Instead they concern a civil action by Mr Pakootas and other members of the Colville tribes and the State of Washington (intervenor) against Teck Cominco Metals Ltd., a Canadian company, before the competent US district courts as designated by CERCLA's citizen suit provision (S. 9659). The latter empowers "any person [to] commence a civil action on his own behalf .... against any person [including the United States and other public authorities] who is alleged to be in violation of any standard, regulation, condition, requirement, or order which has become effective pursuant to this chapter”. Jurisdiction lies with the locally competent federal District Court of the place where the violation occurred - locus delicti. The Court may issue injunctions and/or impose civil penalties. Citizens must first give 60 days notice to the violator as well as relevant public authorities as a condition for admissibility of the action; the US and individual States have a right to intervene.

The key legal issues decided by the Court of Appeals in the Pakootas and others' civil action to enforce the EPA order are that: the river site from which the leaching of the substances took place constitutes a "facility" and a "release" within the meaning of CERCLA; the foreign corporation (operator) comes within the ambit of CERCLA's notions of "any person" and is liable as "arranger" of the release; and no extraterritorial application of CERCLA had occurred. The last conclusion is based on the analysis that the site from which the substances leached was situated entirely within the US and that it did not matter that the substances had originated in Canada and were transported by the river stream across the border. Whether a suit would be characterised as domestic or extraterritorial is determined not by where the operator had initially arranged for the emission of the slag but by the locus of the actual (or threatened) damaging release of the heavy metals etc.; the latter took place in the US not in Canada. The international jurisdiction of the US court over the Canadian operator was based on the generally applicable venue rules for international torts (personal

\footnotetext{
${ }^{142}$ Judgment of 8 November 2004, Not Reported in F.Supp.2d, 2004 WL 2578982 (E.D.Wash.), 35 Envtl. L. Rep. 20,083; [2004] U.S. Dist.LEXIS 23041.
} 
jurisdiction found on place of the harmful event).

We now focus on those aspects with wider implications for transboundary environmental liability suits rather than questions of interpretation of CERCLA. The latter is, however, intricately connected to key questions of transnational litigation and may prove ultimately decisive if the US Supreme Court were to decide to give a ruling. ${ }^{143}$ That is the findings that the Canadian based company constitutes a liable party for having arranged the disposal of hazardous substances as released from the site in the US (a "facility" within the meaning of CERCLA), because it oversaw the emission of the slag into the Columbia river in Canada which subsequently ended up downstream in the US. In essence, the Court of Appeals judgment answers the question whether the citizen suit seeking compliance with the EPA's Order is a domestic or an extraterritorial application of CERCLA. ${ }^{144}$ Canadian based Teck Cominco was held to be liable under CERCLA.

\subsubsection{Extraterritoriality or Not?}

The relevant statute, CERCLA, does not explicitly contemplate its application to non-US based addressees. Is that an indication that the territorial scope cannot reach beyond the US borders? Not necessarily since normally neither regulatory statutes nor liability rules include provisions on their spatial scope; generally speaking, it is a matter of interpretation of the rules in a cross-border setting within the framework of the conflict of laws (notably jurisdiction and choice of law) and/or public international law. Under US law, a presumption exists that legislation applies only within the territorial borders of the US; however, the presumption is merely a canon of interpretation and the US legislator has the power to extend the application of its laws beyond its borders if it intends to do so. Congressional intent may be express or implied. Problematic are situations where addressees of the norm are based or acting outside the territory of the legislator and at the same time subject to the local laws; particularly if this would result in conduct permissible there but prohibited from abroad (a socalled "true conflict"), the presumption against extraterritoriality bites in order to prevent the conflict of norms. However, the picture is quite different where no such conflict arises and effects of the foreign conduct are having an impact in the forum State; normally, sufficient connecting factors would be present to justify the exercise of jurisdiction over the foreign

\footnotetext{
${ }^{143}$ An application for certiorari by Teck Comenceo is pending with the Supreme Court having requested the opinion of the US government in July 2007.

${ }^{144} 452 \mathrm{~F} .3^{\text {rd }}$ at 1068.
} 
based defendant. ${ }^{145}$

There is no bright line rule between a domestic and extraterritorial application of CERCLA; indeed, the lower court had ruled the opposite on this point, albeit that it did conclude there was a permissible extraterritorial application. This is not surprising given the somewhat nebulous nature of the concept of extraterritoriality and its rather less relevant impact in the sphere of liability rules than in the context of regulatory norms. To an extent, all cross-border disputes involving non-contractual liability inevitably involve the application of one State's tort rules to a party based abroad; this in itself can never be disparaged as unacceptable extraterritorial application of laws. Quite rightly, the Court of Appeals underlines that no prescribing of conduct in Canada was in issue, i.e. regulating the discharges, but the assessment of the legal effects of them in the US where harm ensued; the nature of the legislation - liability rather than regulation - is determinative in this regard. CERCLA is not a regulatory statute; it creates liability for remediation (costs) where hazardous substances are released into the environment. ${ }^{146}$ Accordingly, the Court of Appeals could convincingly hold that since the harm was caused by the release of the substances through leachate and that all of this occurred entirely on US territory, a domestic application of CERCLA obtained so that there was no need to examine (rebuttal) of the presumption against extraterritoriality. Teck Cominco is not caught in any conflict of norms with e.g. Canadian law obliging it to act differently from US law. ${ }^{147}$ Notably, no different emission limits are set as CERCLA simply does not cover these; the company is only subject to Canadian regulatory law. ${ }^{148}$

CERCLA focuses on the release of substances with ensuing contamination as the trigger for remediation action so that the relevant connecting factor rightly is the place where that happens rather than the place where the operator initially emitted the substances. There is a clear parallel here with EU civil jurisdiction law under which "place of the harmful event" has been construed, in situations where the impact of the damaging actions are felt in a different State than where the operator had acted, to cover both places with courts having jurisdiction $^{149}$ (see further below). Since the statute (CERCLA) had already made the choice between the two possible places for triggering liability, the Court of Appeals' decision is

\footnotetext{
${ }^{145}$ District Court's judgment, supra note 142 at 5-10, with reference to leading cases.

${ }^{146} 452$ F. $3^{\text {rd }}$ at $1073-1074$.

${ }^{147}$ Even Canadian courts had ruled along these lines in cases about the enforcement of US judgments

in Canada, see Robinson-Dorn, M.J., supra note 137, 295.

${ }^{148}$ Robinson-Dorn, M.J., supra note 137, 272.

${ }^{149}$ Case 21/76 Bier v Mines de Potasse d'Alsace [1976] ECR 1735; [1977] 1 CMLR 284. See the discussion supra in section 3.3 .
} 
convincing.

\subsubsection{Would a European Pakootas be Possible?}

How does the ruling under review compare with current law in the EU? Could a court in e.g. the Netherlands or England rule along the same lines as their US counterparts in a case before it involving, say, a defendant from Germany or Belgium? Like across the Atlantic, matters of substantive liability law (applied in a cross-border context) must be distinguished from questions of private international law (conflict of laws), notably jurisdiction, as seen above. A straightforward "transplant” of the ruling cannot be envisaged as CERCLA contains features - notably the citizen suit provision - which do not exist as such in EU law nor, presumably, in any of the Member States’ domestic laws. ${ }^{150}$ However, there are sufficient similarities between CERCLA and both EC and some domestic laws to explore a possible European equivalent of Pakootas. For a start, the cited Environmental Liability Directive, which required transposition into Member States’ laws by 30 April 2007, and includes many features modelled on CERCLA, in particular the assessment of damage to the environment. ${ }^{151}$ In summary, the ELD establishes liability of operators for (the costs of) preventative and remedial measures where the environment is (threatened to be) harmed. The Directive obliges competent public authorities to compel operators to take these measures or bear their costs when undertaken by the authorities themselves. Members of the public must be able to request the authorities to take action as well as to have access to judicial review of an authority's (planned) action or inaction, as the case may be. In Section 4.3 above, we have already seen that transnational enforcement under the ELD was explicitly contemplated by the community legislature by referring to the Brussels I Regulation.

A tort action would be a possibility either before the court of the domicile of the defendant or before the court of the place where the environmental damage occurred. In terms of jurisdiction, a European Pakootas is entirely conceivable as under Art. 5(3) of the Brussels I Regulation the defendant may be sued before the courts of the place of the harmful event. As noted above, and comparable to Pakootas, this includes the place where the environmental damage arises. Unlike Pakootas, of course, a claim under the ELD cannot be brought by

\footnotetext{
${ }^{150}$ Most of them were covered in the following study prepared for the Commission shortly before it adopted its Proposal for a Directive in 2002: Clarke, Ch., "Update Comparative Legal Study," available from the Commission's Website, URL:

$<$ http://europa.eu.int/comm/environment/liability/legalstudy.htm>.

${ }^{151}$ Supra note 76.
} 
private actors: only public authorities can institute such proceedings.

\subsubsection{Choice of law}

If and when such a cost recovery action were to be instigated by an EU Member State before a competent European court against an operator from another EU Member State, the next question arising would then be about choice of law: which domestic liability regime would govern the dispute? This question did not arise in Pakootas because of the specific cause of action involved: the CERCLA citizen suit seeking enforcement of the EPA's Order and not a free standing private law action by victims of pollution seeking damages and/or injunctive relief. As for the EU, choice of law remains important despite the harmonisation created by the ELD because the Directive deliberately leaves certain matters to domestic law whilst being minimum harmonisation in any event, allowing the application of more protective regimes. This even concerns, as said above, important defences such as State of the Art and the permit defence. ${ }^{152}$ Remarkably, these choice of law questions would seem to remain of far greater importance within the EU than in the Pakootas Canada/US context. Suppose not CERCLA but the relevant legislation of British Columbia had been in issue, no fundamental differences would have arisen as the latter is modelled on CERCLA; if anything, even fewer defences would have been open to Teck Cominco as no permit defence is available under British Columbia law. ${ }^{153}$ However, although available in the US to those operators regulated there, such US operators would not have been better off than Teck Cominco as they would have been liable under other US statues. ${ }^{154}$ Furthermore, no liability for environmental harm abroad would seem to exist under Canadian law when the operator is based there, whereas, it would seem, nothing would prevent the Canadian authorities from applying their version of CERCLA to US polluters in the mirror image scenario of harm in Canada caused by US operators. In fact, the result of Pakootas-style litigation is that operators will be subject to the strictest regime: a race to the top. ${ }^{155}$ That is to say that where courts on both sides of the border take the same approach and apply their own liability rules to foreign based operators who have caused damage in the forum State, a border can never shield operators from liability.

Similarly, in the EU, plaintiffs in future will be able to ensure that operators will be

\footnotetext{
152 See Art. 8(4) ELD.

153 Robinson-Dorn, M.J., supra note 137, 309-312.

${ }^{154}$ District Court judgment in Pakootas, supra note 142, at 14.

155 Robinson-Dorn, M.J., supra note 137, 315-319.
} 
held to account under a regime that suits them - the plaintiffs - best. This follows from the Rome II Regulation which we have already examined above (Section 4.2).

Finally on the possible 'European Pakootas', it was noted above that CERCLA style citizen suit provisions as such are not available in the EU. This is definitely the case for the ELD as it is restricted to access to judicial review of governmental action or failure to act. However, under some Member States’ domestic laws NGOs have standing to bring civil suits, including the use of tort law as a means of enforcing statutory obligations such as in the Sopar case. ${ }^{156}$ Accordingly, some elements of the CERCLA citizen suit are already present in at least one EU jurisdiction.

\section{Effect of a (foreign) license}

An interesting point which will often play a role in (transboundary) environmental pollution cases is that pollution is de facto often covered under a license, that is to say that the discharges take place on the basis of a permit. An important question that always arises in pollution cases is to what extent the fact that a polluter follows the standards laid down in a permit should have a justificatory effect in tort. Legal and economic doctrine is rather divided on that issue. Some hold that when a polluter could take more care at relatively low costs than the level which is laid down in the permit an exposure to liability should provide incentives for additional preventive measures. Thus following regulatory standards or permit condition is merely considered a minimum. A complete “compliance defence” prevents any incentive to take precaution in access of the regulatory standard. ${ }^{157}$ Exposure to liability will thus give the potential polluter incentives to take all preventive measures even is this requires to do more than just following the conditions of a licence. ${ }^{158}$ Others have to the contrary held that judges deciding a tort case should not be second guessing efficient agency decisions. ${ }^{159}$ Bergkamp argues that the polluter should not "pay double”. He holds that the polluter first has to pay to follow the regulatory conditions and next because he has to compensate the victim. He

\footnotetext{
${ }^{156}$ See also Wilde, M., supra note 69, 250 et seq.; De Sadeleer, N., Roller, G. and Dross, M., Access to Justice in Environmental Matters, 2003, Report for the European Commission, available from: $<$ http://ec.europa.eu/environment/aarhus/pdf/accesstojustice_final.pdf>.

${ }^{157}$ See for example Burrows, P., "Combining regulation and liability for the control of external costs", 19 International Review of Law and Economics, 1999, 227-242.

${ }^{158}$ See Kohlstad, Ch., Ulen, Th. and Johnson, G., "Ex post liability for harm vs ex ante safety regulation: substitutes or compliments?”, 80 American Economic Review, 1990, 888-901.

${ }^{159}$ See Rose-Ackerman, S., "Regulation and the law of torts", American Economic Review, 1991, 5458.
} 
therefore argues strongly in favour of a complete regulatory compliance defence. ${ }^{160}$

As a result also the solutions in national environmental liability in the Member States vary considerably. ${ }^{161}$ This divergence will remain in place even after the harmonisation created by the Environmental Liability Directive, because, as noted, this very issue has been left to domestic law. In turn, this underlines the importance of choice of law in future transboundary disputes within the EU; at least from 2009 the Community legislature will have made some contribution to legal certainty in this field because the cited uniform choice of law regime of Rome II will then be in force. Notwithstanding these national variations, there seems to be a common core indicating that the mere fact that a tortfeasor follows regulatory standards or norms of a permit does not free him from liability in tort. The legal policy behind this idea is, as indicated above, that the rights of victims (of pollution) could be seriously limited if a rule were to be applied that victims can no longer hold a polluter liable as long as the polluter follows the emission standards of his permit. The latter solution would only be acceptable if at the moment that permit conditions were laid down, the interests of victims had already been taken into account in the balancing process. Indeed, if interest of victims were already incorporated when setting standards in the permit, a subsequent finding of liability would lead to an inefficient second guessing of agency decisions by the judiciary. However, the latter is of course more particularly a problem when the license is, like in the cases discussed in this contribution, not a license awarded in the victim's State, but a foreign license. On the one hand, one can expect judges to be even more restrictive in accepting tort liability when foreign polluters comply with their license; on the other hand one can equally understand that the interests of victims have usually not been taken into account when standards were laid down in foreign permits. Theoretically, that would hence be a reason not to grant a justificatory effect to foreign licenses. ${ }^{162}$ In all of the Dutch cases we discussed so far the justificatory effect of a permit of the foreign polluter played an important role. In the salt mine case, the French polluter argued that he discharged according to a French permit. The Hoge Raad replies:

\footnotetext{
${ }^{160}$ Bergkamp, L., “A future environmental liability regime”, European Environmental Law Review, 1998, 200-204.

${ }^{161}$ For an overview see Faure, M. and Grimeaud, D., "Financial assurance issues of environmental liability", in Faure, M. (ed.), Deterrence, insurability and compensation in environmental liability. Future developments in the European Union, Vienna, Springer, 2003, $120 \mathrm{ff}$.

${ }^{162}$ See on these issues further Betlem, G. (1993), supra note 6, 424-430.
} 
'In this, the court of appeal comes to the conclusion that the French discharges license, to which MDPA adheres also as regards the regulations, does not have the purport that all illegible interests are weighed to such an extent that the license holder should be shielded from liability in tort. This judgment obviously rests on the explanation of the license and the reservations made therein concerning third-party rights - especially the users of the water who suffered damage judicial discharges, such against the background of the nature and purpose of the relevant French legislation. This judgment, which is properly reasoned, cannot be examined in appeal as to its correctness'.

The court of appeal had established that the French license to which MDAP adhered explicitly mentioned that the permit was given without affecting the rights of third parties. In this case, the conclusion was therefore relatively easy that the French license did not affect the rights of the victims in the Netherlands, since the permit explicitly mentioned this. However, the Hoge Raad seems to suggest that when the foreign license would have weighed the relevant interest in an appropriate way compliance with the permit could have shielded MDA from liability. In other words: in this particular case, the license explicitly excluded a justificatory effect, but the Hoge Raad seems to suggest that there still could be such an effect. ${ }^{163}$ The Hoge Raad decision therefore does not provide a final answer.

The court of appeals of the Hague in the Sopar case is not very brave since it merely forces Sopar to comply with its own Belgian license of which the plaintiff-NGO had held that it violates European norms. The court of appeals de facto only forces Sopar to comply with the conditions of its Belgian permit and implicitly grants a justificatory effect to following the conditions of this permit. Whether there could be liability in tort even though the conditions of this permit were followed (had this been the case) is not examined by the court. This is severly criticized in a case note to the decision since neither under Belgian, nor under Dutch law is there such a justificatory effect of following a permit.

The only decision which seems really to be brave as far as the effect of a permit is concerned is the one of the president of the district court of Maastricht. She establishes that Cockerill has a permit although it contained no norms for the discharge of PAHs. Cockerill had indeed held that the fact that no norms were contained in its permit, was an explicit choice of the administrative authority who wished to have no limitation on the amounts of PAHs discharge.

${ }^{163}$ Betlem, G. (1993), supra note 6, 425-427 and supra section 6.1. 
If that were the case then the subsequent decision of the district court of Maastricht to examine the lawfulness of the PAHs is brave in the sense that this lawfulness is examined irrespective of the Belgian permit of Cockerill. Precisely because she held that there were no precise norms concerning the emission of PAHs, she was only prepared to accept liability of Cockerill if the emissions exceeded 'every reasonable limit' which was according to the president not the case.

In sum, even though on paper following the conditions of a (foreign) license should not have any justificatory effect in a tort action, the Dutch cases illustrate that (with the exception of the MDPA case) it is apparently quite difficult to hold a foreign polluter liable as long as he complies with the conditions of his permit. Only when the permit itself explicitly mentions that it does not affect the rights of third parties (like in the MDPA case) have Dutch judges no difficulty in accepting liability. ${ }^{164}$

\section{Recognition and enforcement}

As we already mentioned above, ${ }^{165}$ a key issue with transboundary pollution cases is of course recognition and enforcement: it may be nice for the plaintiffs in the three Dutch cases we presented to have won their case against the foreign polluters. The question of course arises whether they will also be capable to execute the judgment abroad. Also this was regulated in the Brussels Convention on jurisdiction and the recognition and enforcement of judgments in civil and commercial matters of 1968 and today by Council Regulation 44/2001 of 22 December 2000. The rules are relatively straightforward: according to Article 33 of the Regulation a judgment given in a Member State (for example the Netherlands) shall be recognized in the other Member States without any special procedure being required. Article 34 provides that a judgment shall only exceptionally not be recognized, for example when such a recognition would be manifestly contrary to public policy in the Member State in which recognition is sought (Art. 34 (1)) or when the judgment was given in default of appearance (Art. 34 (2)). One could still consider whether for example Belgium could have argued at the time that the Dutch judgments were 'manifestly contrary to public policy' since a Dutch judge orders the reduction of discharges that they place according to a Belgian

\footnotetext{
${ }^{164}$ See for more details the Second Report by the International Law Association's Committee on Transnational Enforcement of International Environmental Law for the August 2004 biannual Conference in Berlin, supra note 28, para. 3.5.

${ }^{165}$ See supra section 3.
} 
permit. A shrewd attorney could try to argue that recognizing the Dutch judgment would hence be manifestly contrary to public policy in Belgium. That argument would, however, not be very strong since also according to Belgian law (as we showed above) permits do not have a justificatory effect in tort. Moreover, in the Sopar case the Belgian company was precisely condemned to follow the conditions of the Belgian license, which can be hardly considered contrary to its public policy. Another reason could be that some Member State might argue that plaintiffs were non-governmental organizations whereas in their country NGO's would not have standing. However, today standing of non-governmental organizations is almost generally recognized in all Member States. Moreover, article 36 provides that 'under no circumstances may a foreign judgment be reviewed as to its substance’.

Since recognition is in principle 'automatic' plaintiffs can move to the enforcement of the judgment on the basis of Article 38: 'A judgment given in a Member State and enforceable in that State shall be enforced in another Member State when, on the application of any interested party, it has been enforceable there'. In that case the plaintiff will submit an application for enforcement to the court or competent authority indicated in the list in annex II to the regulation. However, also as far as enforcement is concerned, Article 45(2) holds that 'under no circumstances may the foreign judgment be reviewed as to its substance'.

An interesting feature in some of the Dutch cases we discussed was that the court ordered the defendant to take specific measures and ordered a penalty payment for the case of noncompliance. Also that should not be a problem from the perspective of recognition and enforcement. Article 49 of the regulation provides: 'A foreign judgment which orders a periodic payment by way of a penalty shall be enforced in the Member State in which enforcement is sought only if the amount of the payment has been finally determined by the courts of the Member State of origin'. Since, for example in the Sopar case, the amount of the penalty payment was finally determined by the court of appeals also the penalty payment can in principle be enforced in Belgium.

In sum, the Brussels I Regulation provides sufficient possibilities to victims who obtained a successful judgment in the victim's State to enforce their judgment subsequently in the polluter's State. Of course problems may still arise at the practical level. One could, for example wonder how the NGO Reinwater will have the possibility to verify whether defendant Sopar will in the future actually comply with the conditions of the Belgian permit, 
but even there solutions could be worked out to overcome these practical difficulties. ${ }^{166}$

\section{Conclusions}

Traditionally lawyers primarily think of international law as the instrument to cure transboundary pollution cases. Instruments of international law like conventions and multilateral environmental treaties may undoubtedly play an important role in that respect. However, the focus of our contribution was a different one. We tried to show that sometimes also national civil law can be applied to these transboundary pollution cases in such a way that victims can successfully attempt to obtain an order forcing foreign polluters to reduce their transboundary pollution.

The purpose of our contribution was to use a few examples mainly from the Netherlands, but also from the US to show that if particular conditions are met victims can successfully use private law. We therefore tried to provide an inventory of issues that potential victims may come across in their attempt to use private law in the fight against transboundary pollution. The example of the Netherlands shows that there are (of course depending upon the willingness of the judiciary) ample possibilities for such a transboundary application of national civil law. A crucial issue which will often arise is whether victims have the right to bring the tort suit in their own country. In legal practice this question may often be far more important than e.g. the question whether a strict liability or a fault regime applies. We showed that the case law of the European Court of Justice in the Bier case allows victims to bring their suit not only in the place where the emissions took place (often where the polluter is situated) but also in the place where the damage occurs (usually the place where the victim resides). Moreover, we equally showed that in some Member States (such as the Netherlands) also in cases where harm is widespread and individual victims do not have sufficient interests to bring a liability claim NGO's may have standing e.g. to claim an injunction to stop the pollution on behalf of the environment.

As for questions of private international law (conflict of laws), significant progress has been made in Europe over the last four decades or so in terms of removing obstacles to cross-

\footnotetext{
${ }^{166}$ One could imagine a liaison between the NGO and the administrative authorities in the polluter's State whereby the administrative authorities would cooperate to verify whether there is actual compliance with the permit.
} 
border litigation against polluters. As already mentioned, plaintiffs have the right to choose the forum they consider most appropriate in that, at their option, a case can be brought before the court of the defendant's domicile, a court at the place where polluting acts took place (if different from the first one), where the environmental damage occurred (normally coinciding with the plaintiff's home State) or, where a group of legal persons is concerned, at the place of a branch of the parent company (again, insofar as that place is not overlapping with any of the other ones). From 2009, plaintiffs will also be able to select the most appropriate liability regime as their most favourable law under the Rome II Regulation. Or agree on the applicable law with the defendant. In any event, the considerable legal uncertainty about both venue and applicable law, which deters victims from suing in the first place has been reduced to more manageable levels.

Under Dutch law, the courts have made important contributions by adapting basic rules of tort law, the law of damages and civil procedure to make them useful in a transboundary context. Injunctive relief has been made available to ensure compliance with statutory obligations regardless of the origin of the rules: domestic or foreign. In addition, defendants based outside The Netherlands must comply with orders issued by the Dutch courts both within and out with the jurisdiction of the court issuing the injunctions. Such orders are backed up by periodic penalty payments. All these judgments are fully enforceable in any other EU Member State under the Brussels I Regulation. In effect, Dutch law also recognises an equivalent form of US style citizen suits with which any interested person is able to apply to a civil court to ensure compliance with relevant environmental legislation in both a domestic and transfrontier setting. However, whether the recent US Trail Smelter II litigation can be exactly exported to the EU remains to be seen. That case illustrates, in our view, the importance of the use of civil remedies in transboundary pollution cases. It demonstrates how civil law cannot only be used to enforce statutory norms but also administrative decisions ordering foreign defendants to take remedial action. That is a valuable lesson from across the Atlantic. 


\section{List of References}

Allen, M., "Liability for climate change. Will it ever be possible to sue anyone for damaging the climate?”, 421 Nature, 2003, 891-892.

Asser-Hartkamp I (C. Asser's Handleiding tot de beoefening van het Nederlands burgerlijk recht, Verbintenissenrecht, Deel I, De verbintenis in het algemeen), No. 414.

Bauw, E. and Brans, E.H.P., Milieuprivaatrecht, $3^{\text {rd }}$ ed., Deventer, Kluwer 2003.

Bauw, E. and Frenk, N., “Nieuwe perspectieven voor milieu-organisaties”, Nederlands Juristenblad 1991, 1259-1264.

Bergkamp, L., “A future environmental liability regime”, European Environmental Law Review, 1998, 200-204.

Betlem, G., Civil Liability for Transfrontier Pollution. Dutch Environmental Tort Law in International Cases in the Light of Community Law, London, Graham and Trotman, 1993.

Betlem, G., "Legal Barriers to Liability for Cross-Border Non-Point Source Pollution”, in Van Dunné, J.M. (ed.), Non-Point Source River Pollution. The Case of the River Meuse. Technical, Legal, Economic and Policy Aspects, London, Kluwer Law International, 1996, 145-158.

Betlem, G., [Recovery of Costs by Environmental NGOs] "Kostenverhaal door milieuorganisaties”, in Van Buren-Dee J.M. et al. (eds.), Privaatrecht en Gros. Liber Amicorum F.W. Grosheide, AntwerpenGroningen, Intersentia, 1999, 133-146.

Betlem, G., “Transnational Litigation against Multinationals before Dutch Courts,” in Kamminga, M. and Zia-Zarifi, S. (eds.), Liability of Multinational Corporations under International Law, The Hague, Kluwer Law International, 2000, 283-305.

Betlem, G., "Strict environmental liability and NGO damages and enforcement claims: a Dutch and international law perspective”, in Hamer, J. (ed.), Environmental Liability in the EU, Trier, ERA, 2002, 131-143.

Betlem, G., "Environmental Liability and the Private Enforcement of Community Law", in Hartkamp, A. et. al. (eds.), Towards a European Civil Code, Nijmegen, Ars Aequi Libri, 2004, 677-696.

Betlem, G., “Transnational Operator Liability”, in Betlem, G. and Brans, E. (eds.), Environmental Liability in the EU. The 2004 Directive compared with US and Member State Law, London, Cameron May, 2006, 149-188.

Betlem, G., "Trail Smelter II: Transnational Application of CERCLA - Pakootas v. Teck Cominco Metals Ltd., 452 F.3rd 1066 (9th Cir. 2006),” 19(3) Journal of Environmental Law, 2007, forthcoming.

Betlem, G. and Bernasconi, C., "European Private International Law, the Environment and Obstacles for Public Authorities,” 122 Law Quarterly Review, 2006, 123-150.

Betlem, G. and Faure, M., "Environmental Toxic Torts in Europe: Trends in Recovery of Soil CleanUp Costs and Damages for Personal Injury in the Netherlands, Belgium, England and Germany", Georgetown International Environmental Law Review, 1998, 855-890.

Birnie, P.W. and Boyle, A., International Law and the Environment, $2^{\text {nd }}$ ed., Oxford, OUP, 2002. 
Bratspies, R.M. (ed.), Transboundary Harm in International Law: Lessons from the Trail Smelter Arbitration, Cambridge, CUP, 2006.

Bratspies, R.M. and Miller, R.A. (eds.), Transboundary Harm in International Law: Lessons from the Trail Smelter Arbitration, Cambridge, CUP, 2006.

Briggs, A., The Conflict of Laws, Oxford, OUP 2002.

Brownlie, I., Principles of Public International Law, $6^{\text {th }}$ ed., Oxford, OUP, 2003.

Burrows, P., "Combining regulation and liability for the control of external costs", 19 International Review of Law and Economics, 1999, 227-242.

Carette, A., Herstel van en vergoeding voor aantasting aan niet-toegeëigende milieubestanddelen, Antwerpen-Groningen, Intersentia, 1997.

Clarke, Ch., "Update Comparative Legal Study,” available from the Commission's Website, URL: $<$ http://europa.eu.int/comm/environment/liability/legalstudy.htm>.

Cohen, M., “Commentary”, in Eide, E. and Van den Bergh, R.J. (eds.), Law and Economics of the Environment, Oslo, Juridisk Forlag, 1996, 167-171.

Craig, P and De Burca, G., EU Law. Text Cases and Materials, $4^{\text {th }}$ ed., Oxford, OUP, 2008.

Degros, Ch., "La responsabilité civile nucléaire: un état des lieux”, in Viney, G. and Dubuisson, B. (eds.), Les responsabilités environnementales dans l'espace Européen. Point de vue franco-belge, Brussels, Bruylant, 2006, 303-374.

Van Dunné, J.M. (ed.), Transboundary Pollution and Liability: the Case of the River Rhine, Vermande, Lelystad, 1991.

Van Dunné, J.M. (ed.), Non-Point Source River Pollution: the Case of the River Meuse. Technical, Legal, Economic and Political Aspects, London, Kluwer Law International, 1996.

Esty, D., “Revitalizing Environmental Federalism”, 95 Michigan Law Review, 1996, 570-653.

Faure, M., "Juridische Problemen bij de Bestrijding van Grensoverschrijdende Waterverontreiniging” (Case note by Court of Appeal The Hague, 19 November 1992 and President Civil Court of Maastricht, 3 February 1993), Tijdschrift voor Milieurecht, 1993, 157-162.

Faure, M. and Grimeaud, D., "Financial assurance issues of environmental liability", in Faure, M. (ed.), Deterrence, insurability and compensation in environmental liability. Future developments in the European Union, Vienna, Springer, 2003, 7-255.

Faure, M. and Lefevere, J., “Compliance with Global Environmental Policy”, in Axelrod, R.S., Downie, D.L., Vig, N.J. (eds.), The Global Environment. Institutions, Law and Policy, $2^{\text {nd }}$ edition, Washington, CQ Press, 2004, 163-180.

Faure, M. and Nollkaemper, A., "International liability as an instrument to prevent and compensate for climate change”, Stanford Environmental Law Journal (26A)/ Stanford Journal of International Law (43A), Symposium Issue June 2007, 123-179. 
French, D.A., “The 1999 Protocol on Liability and Compensation for Damage Resulting from the Transboundary Movements of Hazardous Wastes and their Disposal,” Environmental Liability, 2000, 3-11.

Frenk, N. and Messer, E.A., “Ongekende mogelijkheden voor milieuorganisaties!?”, Kwartaalbericht Nieuw BW, 1991, 14-17.

Gauci, G., Oil Pollution at Sea. Civil Liability and Compensation for Damage, Chichester etc., Wiley, 1997.

Grosman, D.A., "Warming up to a not-so radical idea: tort-based climate change litigation”, 28 Columbia Journal of Environmental Law, 2003, 1-61.

Gupta, J., Who's afraid of climate change? Inauguration address Free University of Amsterdam, 2005.

Haanappel, P.P.C. and Mackaay, E., New Netherlands Civil Code: Patrimonial Law, Deventer-Boston, Kluwer, 1990.

Horbach, N.L.J.T., Liability versus responsibility under international law. Defending strict State responsibility for transboundary damage, diss. Leiden, 1996.

Jacobsen, H.K. and Brown Weiss, E., "Strenghtening Compliance with International Environmental Accords: Preliminary Observations, from a Collaborative Project”, 1 Global Governance, 1995, 119148.

Kimber, C., "A Comparison of Environmental Federalism in the United States and the European Union”, 54 Maryland Law Review, 1995, 1658-1690.

Knox, J.H., "The Flawed Trail Smelter Procedure: The Wrong Tribunal, the Wrong Parties and the Wrong law,” in Bratspies, R.M. and Miller, R.A. (eds.), Transboundary Harm in International Law: Lessons from the Trail Smelter Arbitration, Cambridge, CUP, 2006, 66-78.

Kohlstad, Ch., Ulen, Th. and Johnson, G., "Ex post liability for harm vs ex ante safety regulation: substitutes or compliments?”, 80 American Economic Review, 1990, 888-901.

Kottenhagen-Edzes, P., "De begrippen milieu-aantasting en milieuschade in enkele internationale verdragen, bezien vanuit privaatrechtelijk perspectief," in Deketelaere, K. et al. (eds.), Grensoverschrijdende milieuproblemen: uitdagingen voor de nationale en internationale rechtsorde, Antwerpen-Groningen, Intersentia, 1998, 207-223.

Krämer, L., “Directive 2004/35 on environmental liability and environmental principles,” Special issue of TMA on the ELD, 4 TMA, 2005, 131-134.

Kreuzer, K., "Die Vergemeinschaftung des Kollisionsrechts für ausservertragliche Schuldverhältnisse (Rom II)", in Reichelt, G. and Rechberger, W.H. (eds.), Europäisches Kollisionsrecht (anwendbares Recht; gerichtliche Zuständigkeit; Vollstreckung von Entscheidungen im Binnenmarkt), Vienna, Manz-Verlag, 2004, 13-62.

Larsson,M.-L., The Law of Environmental Damage. Liability and Reparation, The Hague and Stockholm, Kluwer Law International \& Norstedts Juridik, 1999.

Lefebre, R., Transboundary environmental interference and the origin of State liability, The Hague, Kluwer Law International, 1996. 
Messer, E.A., Risico-aansprakelijkheid voor milieuverontreiniging in het BW, Arnhem, Gouda Quint, 1994.

Mitchell, R.B., “Compliance Theory: an Overview”, in Cameron, J., Werksman, J. and Roderick, P. (eds.), Improving Compliance with International Environmental Law, London, Earthscan, 1996, 3-28.

Nollkaemper, P.A., "How Public International (Environmental) Law can furnish a Rule of Decision in Civil Litigation”, Tijdschrift voor Milieuaansprakelijkheid (Environmental Liability Review), 1998, 34.

Nollkaemper, P.A. et al., De nationale rechter en het internationale recht, Den Haag, Mededelingen NVIR 131, 2005, preadviezen.

Oates, W. and Schwab, R., "Economic Competition among Jurisdictions: Efficiency Enhancing or Distortion Inducing?”, 35 Journal of Public Economic, 1988, 333-354.

Polak, M.V., Civiele Sancties in het Internationale Geval voor de Nederlandse Rechter, Studiekring "Prof.mr. J. Offerhaus", Deventer, Kluwer, 1995.

Rest, A., "International Environmental Liability Law before German Courts”, Tijdschrift voor Milieuaansprakelijkheid (Environmental Liability Review), 1997, 116-122.

Robesin, M.A., "Procedeerlust Opwekkend en Remmend Privaatrecht", in Van Acht, R.J.J. and Sicking, G.C. (eds.), Privaatrecht en milieu, Zwolle, Tjeenk Willink, 1994, 49-70.

Robinson-Dorn, M.J., “The Trail Smelter: Is What's Past Prologue? EPA Blazes a New Trail for CERCLA,” 14 N.Y.U. Env. L.J., 2006, 233-321.

Rose-Ackerman, S., "Regulation and the law of torts", American Economic Review, 1991, 54-58.

De Sadeleer, N., Roller, G. and Dross, M., Access to Justice in Environmental Matters, 2003, Report for the European Commission, available from:

http://ec.europa.eu/environment/aarhus/pdf/accesstojustice_final.pdf.

Sands, Ph., Principles of International Environmental Law, $2^{\text {nd }}$ ed., Cambridge, Cambridge University Press, 2003.

Shavell, S., “Liability for harm versus regulation of safety”, Journal of Legal Studies, 1984, 357-374.

Shavell, S., “A model of the optimal use of liability and safety regulation”, Rand Journal of Economics, 1984, 271-280.

Spier, J., "Legal aspects of global climate change and sustainable development”, Revista para el Analysis del Derecho, 346, April 2006, available at http://www.indret.com/pdf/346_\&pdf.

Spier, J. et al., Verbintenissen uit de wet en Schadevergoeding, 4th ed., Deventer, Kluwer, 2006.

Stone, P., EU Private International Law, Cheltenham/Northampton, Edward Elgar, 2006.

Strikwerda, L., Inleiding tot het Nederlandse internationaal privaatrecht, 8th ed., Deventer, Kluwer, 2005.

Symeonides, S.C., “Tort Conflicts and Rome II: a View from Across”, in Mansel, H.-P., et al. (eds.), Festschrift für Erik Jayme, Munhcen, Sellier/European Law Publishers, 2004, 935-954. 
Vanden Borre, T., 'Shifts in governance in compensation for nuclear damage, 20 years after Chernobyl', in Faure, M. and Verheij, A. (eds.), Shifts in Compensation for Environmental Damage, Vienna, Springer, 2007, 261-311.

Verheyen, R., Climate change damage and international law: prevention, duties and State responsibility, Leiden, Nijhoff, 2005.

Vlas, P., "Het Verdrag inzake aansprakelijkheid voor milieugevaarlijke activiteiten en het internationaal privaatrecht”, Aansprakelijkheid \& Verzekering, 1993, 25-33.

Widmer, P. (ed.), Unification of Tort Law: Fault, The Hague, Kluwer Law International, 2005.

Wilde, M., Civil liability for environmental damage a comparative analysis of law and policy in Europe and the United States, The Hague, Kluwer, 2002.

Wu C., Pollution from the Carriage of Oil by Sea: Liability and Compensation, London etc., Kluwer, 1996. 